KuLTura - MeDia- TeoLogia

ISSN 2081-8971

$2017 \mathrm{nr} 29$, s. 86-111.

Piotr Jakubowski, Wydział Nauk Humanistycznych UKSW

\title{
Uchodźcy jako kozioł ofiarny ver. 2.0 . Figury i schematy internetowej mowy nienawiści wokół tzw. kryzysu migracyjnego
}

The Refugees as a „Scapegoat" ver. 2.0. On the Figures and Schemas of Online Hate Speech around the Migrant Crisis.

\section{STRESZCZENIE:}

W NINIEJSZYM TEKŚCIE PODDAJĘ ANALIZIE FIGURY MECHANIZMU KOZŁA OFIARNEGO I ZWIĄZANEJ Z NIM WYOBRAŹNI PRZEŚLADOWCZEJ (JAK PRZEDSTAWIŁ JE RÉNE GIRARD), OBECNE W SPOŁECZNEJ REAKCJI NA TZW. KRYZYS MIGRACYJNY. PUNKTEM WYJŚCIA SĄ KOMENTARZE INTERNAUTÓW UMIESZCZONE POD ZDJĘCIAMI UCHODŹCÓW PRZYŁAPANYCH PODCZAS PRÓBY PRZEDOSTANIA SIĘ PRZEZ KANA€ LA MANCHE NA NACZEPIE CIĘŻARÓWKI. FOTOGRAFIE TE ZOSTAŁY ZAMIESZCZONE NA FACEBOOKOWYCH FANPAGE'ACH

MARIUSZA PUDZIANOWSKIEGO (POLSKIEGO STRONGMANA I ZAWODNIKA MMA) ORAZ JEGO FIRMY SPEDYCYJNEJ I WYWOŁAŁY LAWINĘ MOWY NIENAWIŚCI SKIEROWANEJ W STRONĘ UCHODŹCÓW. INTERNETOWY HEJT PRZEDSTAWIAM TU NIE JAKO ZUPEŁNIE NOWE ZJAWISKO, CHARAKTERYSTYCZNE DLA ZDIGITALIZOWANEGO ŚWIATA, LECZ JAKO KOLEJNE WCIELENIE PRASTAREGO MECHANIZMU PRZEŚLADOWCZEGO. ODWOŁUJĄC SIĘ DO ANALIZ GIRARDA I PROJEKTU „POLITYKI PERFORMATYWU” JUDITH BUTLER, STARAM SIĘ PRZEDSTAWIĆ MOŻLIWOŚĆ ODPOWIEDZI NA KRZYWDZĄCE EFEKTY MOWY NIENAWIŚCI - PROPOZYCJE TWORZENIA TEGO, CO OKREŚLAM JAKO „EWANGELIE UCHODŹCZE”.

\section{SŁOWA KLUCZOWE:}

UCHODŹCY, MOWA NIENAWIŚCI, KOZIOŁ OFIARNY, PRZEMOC, PODPORZĄDKOWANY INNY, WYOBRAŹNIA PRZEŚLADOWCZA

\begin{abstract}
:
THE MAIN GOAL OF MY ESSAY IS TO DEPICT AND ANALYZE SOME SPECIFIC IMAGINATIVE FIGURES OF WHAT RÉNE GIRARD CALLED A 'SCAPEGOAT MECHANISM', AS THEY APPEAR IN CONTEMPORARY CONTEXT OF SOCIAL REACTION TO SO CALLED REFUGEE CRISIS. I FOCUS ON INTERNET USERS' COMMENTARIES POSTED BELOW THE IMAGES SHOWING A FEW REFUGEES CAUGHT WHILE TRYING TO DRIVE THROUGH ENGLISH CHANNEL HIDDEN IN TRUCK TRAILER. THOSE PHOTOS HAS BEEN UPLOADED By MaRiusz 'PudZian' PUDZIANOWSKI (POLISH STRONGMAN AND MMA FIGHTER) ON HIS AND HIS SHIPPING COMPANY'S FACEBOOK FANPAGES, AND CAUSED A TREMENDOUS OVERFLOW OF INTERNET HATE SPEECH. HERE I PRESENT IT NOT AS A BRAND NEW PHENOMENA OF DIGITALIZED WORLD, BUT RATHER AS A SUBSEQUENT VERSION OF A PRIMEVAL PERSECUTIVE MECHANISM. BY REFERRING TO BOTH GIRARD'S ANALYSES AND JUDITH BUTLER'S CONSIDERATIONS ON THE “POLITICS OF THE PERFORMATIVE", I TRY TO SET OUT SOME WAYS OF POSSIBLE ANSWERS TO HARMFUL EFFECTS OF INTERNET HATE AIMED AT MIGRANTS, THAT IS - A PROJECT OF “REFUGEE GOSPELS".
\end{abstract}

\section{KEYWORDS:}

REFUGEES, HATE SPEECH, SCAPEGOAT MECHANISM, VIOLENCE, SUBALTERN, PERSECUTIVE IMAGINATION 
Kryzys uchodźczy zbiegł się w Polsce z kryzysem niektórych standardów demokratycznych. Mam wrażenie, że wiele osób [...] poczuło się obezwładnionych skalą naruszeń różnych norm społecznych i wartości, do przestrzegania których byli dotąd przyzwyczajeni.

Adam Bodnar

W niniejszym szkicu praktyki internetowych hejterów analizuję poprzez odniesienie do zachowań charakterystycznych dla tłumu. Internetowa mowa nienawiści przedstawiana jest jako poważny problem i zagrożenie społeczno-kulturowe (np. w służącej mi za motto wypowiedzi Rzecznika Praw Obywatelskich), a jednocześnie gros badań wskazuje, że stanowi ona jedynie niewielki procent różnych form aktywności użytkowników internetu². Tym jednak, co czyni ją szczególnie dostrzegalną - a tym samym niebezpieczną - jest zdolność do ogniskowania się i kumulowania w określonych wirtualnych rewirach (głównie wyznaczonych tematycznie), co może stanowić wstępne uzasadnienie dla myślenia o sieciowych hejterach właśnie w kategoriach tłumu.

Teoretyczną ramę obrazującą schematy działania tłumu zaczerpnę nie z różnych koncepcji z zakresu psychologii społecznej, lecz z mitograficznej antropologii René Girarda, który za podstawowy mechanizm działania rzesz ludzkich uznał mimetyzm, sprzężony ze współdzielonym konglomeratem imaginacyjnym o archaicznym rodowodzie, określonym przez niego jako „wyobraźnia prześladowcza”. „Jednostki składające się na tłum - pisze Girard - zawsze są potencjalnymi prześladowcami, bowiem marzy im się oczyszczenie wspólnoty z elementów nieczystych, które ją demoralizują"”3.

O grupach internautów w kategoriach tłumu pisała już Magdalena Szpunar w książce Kultura cyfrowego narcyzmu. Odnosząc się do licznych badań, autorka wskazywała, iż „rozmyte ja jednostki, które staje się częścią podmiotu zbiorowego, łatwo ulega wrażeniu, że nie ponosi odpowiedzialności za swe czyny, gdyż potencjalna wina zostaje przeniesiona na innych. Inni decydują, inni wybierają, a ona jedynie poddaje się obezwładniającej woli internetowego tłumu"4. Stwierdzenie to splata ze sobą wymiar tożsamościowy i moralny (jednostka zostaje niejako pozbawiona mocy samostanowienia i wyboru, ubezwłasnowolniona, poddana działaniu siły kolektywnej woli, uosabianej przez innych, ale niedającej się do nich sprowadzić, bowiem „podmiot zbiorowy” zawsze jest czymś więcej niż sumą swoich składowych).

Jednakże tożsamościowe „rozmycie” jednostki, a wraz z tym zniesienie jej pełnej odpowiedzialności za własne czyny, nie może stanowić żadnego alibi dla krzywd wynikających z jej/nie-jej postępowania. Pewna forma podmiotowego wywłaszczenia jest bowiem warunkiem koniecznym mowy nienawiści, o ile ma być ona działaniem skutecz-

\footnotetext{
1 Uchodźcza opozycja, rozmowa z Adamem Bodnarem, Rzecznikiem Praw Obywatelskich, „Tygodnik Powszechny", nr 1-2/2017, s. 113.

2 Zob. np. M. Troszyński, Fundacja Wiedza Lokalna, Raport Mniejszości, Warszawa 2012.

3 R. Girard, Kozioł ofiarny, przeł. M. Goszczyńska, Łódź 1987, s. 26.

4 M. Szpunar, Kultura cyfrowego narcyzmu, Kraków 2016, s. 151.
} 
nym (tzn. jednocześnie wypowiadającym nienawiść, jak i będącym aktem nienawiści). Hejter - jak będę starał się wykazać, powołując się na rozważania Judith Butler - zawsze (tylko i aż) „cytuje” innych. Ci z kolei „,cytują” szersze formacje myślowe i dyskursywne, których horyzont czasowy sięga daleko wstecz względem samego aktu cytowania i, z jednej strony, wyznacza warunki jego możliwości i skuteczności, z drugiej - dostarcza najmocniejszych argumentów za przeciwstawianiem się mu. „Raniące słowo” zawsze jest by powołać się na Michaiła Bachtina - słowem „cudzym”, zachowującym pamięć o swoich wcześniejszych użyciach. Zatem choć hejter nie może ponosić odpowiedzialności za samo słowo i moc ranienia, do której jest ono zdolne, to przez sam akt „cytowania” przywołuje i ożywia on wszelkie konteksty upokorzeń i wzgardy, dyskryminacji i prześladowań, wpisując się w całą historię przemocy zogniskowaną w jednym „raniącym słowie" i transmitowaną przez nie.

W pierwszej części niniejszego tekstu staram się naszkicować - zdawkowo, gdyż bazując wyłącznie na własnych doświadczeniach wywiedzionych z pracy dydaktycznej oraz uczestnictwa w życiu społeczno-kulturalnym - szeroki kontekst, jakim jest społeczna reakcja na tzw. kryzys migracyjny. W części drugiej przedstawiam konkretny przypadek owej reakcji - wylew mowy nienawiści, jaki nastąpił po publikacji na facebookowych fanpage'ach sportowca Mariusza Pudzianowskiego oraz jego firmy spedycyjnej zdjęć przedstawiających uchodźców przyłapanych podczas próby nielegalnego przekroczenia kanału La Manche w przyczepach tirów. W części trzeciej natomiast analizuję konkretne figury tej mowy, odnosząc je do szerszych schematów dyskursywnych i wyobrażeniowych, tworzących to, co Girard określił jako „wyobraźnia prześladowcza”. W zakończeniu wyjaśniam ideę „ewangelii uchodźczych” jako polityczno-tekstualnej broni przeciw mowie nienawiści.

\section{Od widoku cudzego cierpienia po wrogościnność ${ }^{5}$ stosowaną - zarys (szerszego) kontekstu}

Kiedy w 2012 roku Jarosław Mikołajewski próbował umówić się na spotkanie z Guisi Nicolini, burmistrzynią Lampedusy, małej włoskiej wyspy na Morzu Śródziemnym, do której każdego praktycznie dnia dopływały przepełnione statki z uchodźcami z terytorium Libii, przekonywał „o konieczności nagłośnienia problemu”. Jak wskazywał „Europa słabo reaguje, bo jest niedoinformowana [...]. Niedostatecznie poruszona. Zapewniałem, że jeśli Polska dowie się o tysiącu pięciuset uchodźcach stłoczonych na trzystu miejscach w Centrum Identyfikacji i Ekstradycji na Lampedusie, to zareaguje. Jeśli usłyszy, że wyspa jest za mała, żeby pochować tysiące trupów - pomoże” ${ }^{6}$.

5 Określenie to jest polskim tłumaczeniem neologizmu Jacques’a Derridy hostipitalité. Zob. J. Derrida, Wrogościnność, przeł. A. Dwulit, w: Wrogościnność. Podejmowanie obcych / Hostipitality. Receiving Strangers, publikacja towarzysząca wystawie Wrogościnność. Podejmowanie obcych, Muzeum Sztuki w Łodzi, 17.09-19.10.2010, Łódź 2010, s. 6-23. Początek tytułu podrozdziału pochodzi, oczywiście, od Susan Sontag.

6 J. Mikołajewski, Wielki przypływ, Warszawa 2015, s. 10. Giusi Nicolini została w 2016 roku uhonorowana Medalem Świętego Jerzego, przyznawanym przez „Tygodnik Powszechny”, za - jak uzasadniono „walkę ze smokiem obojętności i uprzedzeń”. W wypowiedzi po odebraniu nagrody burmistrzyni mó- 


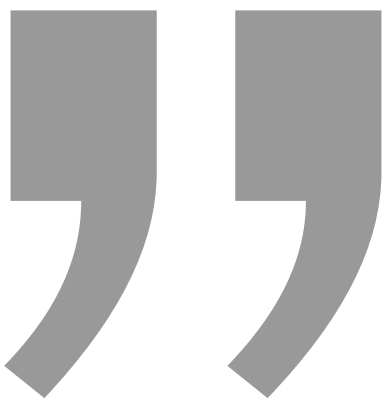

W jednej ze swych ostatnich prac Zyǵmunt Bauman pisał w tym kontekście 0 „adiaforyzacji problemu migracyjnego (czyli wyłączeniu migrantów i tego, co się z nimi dzieje, z moralnej oceny). Gdy opinia publiczna już raz ich zakwalifikuje jako potencjalnych terrorystów, migranci trafiają poza granice i zasięg moralnej odpowiedzialności - oraz, przede wszystkim, poza przestrzeń współczucia".

W semestrze letnim roku akademickiego 2014/15 prowadziłem ze studentkami kulturoznawstwa zajęcia z przedmiotu o nazwie „Dialog i polilog kultur”. Zaczęliśmy od klasyki filozofii dialogu i spotkania, relacji z Innym lub Obcym - Waldenfels, Agamben, Derrida, Kapuściński - komunikacji międzykulturowej i strategiach wielokulturowości. Stopniowo jednak zaczęliśmy odczuwać coraz bardziej palącą konieczność skupienia się na sprawach bieżących, bo był to właśnie ten moment, w którym Europa „usłyszała” o napływie uchodźców. Informacje o masowych zatonięciach i łodziach wypełnionych wycieńczonymi, półżywymi i zmarłymi podczas transportu uciekinierami z terenów Afryki i Bliskiego Wschodu zaczęły wypełniać pierwsze strony gazet i portali informacyjnych, zaś rozwiązanie tego, co wkrótce zostanie nazwane kryzysem migracyjnym, a potem uznane za największą katastrofę humanitarną od czasów II wojny światowej, stało się priorytetowym problemem polityki unijnej, stopniowo przerzucanym na barki administracji państw członkowskich. Przygotowując dla studentek wyciąg z doniesień internetowych dotyczących projektu tak zwanego kwotowego podziału uchodźców między krajami Unii, spojrzałem na komentarze pod jednym z artykułów. Koniec końców to one właśnie, nie zaś same teksty, stały się podstawą dyskusji na zajęciach. W obliczu tego, o czym mówiliśmy do tej pory - fenomenu spotkania, ideałów dialogiczności i gościnności itd. - komentarze sugerujące, w najłagodniejszej wersji, zatapianie łodzi z uchodźcami wydawały nam się trudne do pojęcia, naruszające elementarne, zdawałoby się, normy i wartości naszej kultury.

wiła: „, Myślę, że nikt z nas nie powinien bezczynnie czekać, aż rządu europejskie przekonają się w końcu, że prowadzona przez nie polityka zamkniętych granic prowadzi do śmierci, bólu i desperacji. Nie możemy czekać, aż rządzący zrozumieją, że podsycanie strachu - tylko po to, aby wyglądać na silnych w oczach swych współobywateli - nie rozwiązuje problemu bezpieczeństwa [...]. Mam nadzieję, że to właśnie z Polski może ponownie wyjść przesłanie solidarności; że wasz kraj na powrót stanie się jej symbolem, jak to było przez długi okres najnowszej historii” (cyt. za: M. Żyła, Lampedusa, granica Polski, „Tygodnik Powszechny”, nr 3/2017, s. 14). 
Mieliśmy wszelako wygodne antidotum na niepokój z tym związany, zdążyliśmy się bowiem już przyzwyczaić, że w dyskusjach na czatach i forach internetowych pełno jest bytów, które za nic sobie mają niepisane zasady interakcji personalnych i wspólnotowego współistnienia. Potrafiliśmy też spacyfikować te byty, korzystając ze stereotypowego wizerunku trolla czy hejtera - to znudzone małolaty („gimbaza”), które rozochocone względną anonimowością i nikłą perspektywą jakichkolwiek reperkusji ${ }^{7}$ wyładowują swoje niepowodzenia i frustracje z „realu”, czerpiąc ze swych działań online złudne poczucie siły i sprawczości. Tym jednak, co nie przestawało budzić niepokoju, była skala tego zjawiska i obecna w większości komentarzy pewna nadwyżka agresywnej zapalczywości, która znacznie wykraczała poza normy reakcji lękowej czy napastliwej nawet krytyki. No, ale czy naprawdę trzeba brać na poważnie to, co ludzie wypisują w Internecie...

Z perspektywy czasu uważam, że diagnoza, którą postawiliśmy owym sieciowym bytom, odnosiła się i do nas: tak jak oni mogli robić to, co robili, gdyż nie dostrzegali realnego człowieka po drugiej stronie ekranu, tak też i my widzieliśmy w nich wyłącznie jakieś abstrakcyjne twory, którym za pomocą podręcznego profilu psychologicznego przyprawialiśmy czysto teoretyczną ,gębę”, co zwalniało nas z konieczności liczenia się $\mathrm{z}$ nimi jako realną siłą społeczną. Ale historia toczyła się dalej.

W połowie czerwca 2015 roku udaliśmy się ze studentkami na spotkanie dyskusyjne w Muzeum Historii Żydów Polskich POLIN zatytułowane „Sytuacja uchodźców i programy ich integracji”. Po rozmowie, jedna z osób z widowni, młoda aktywistka z organizacji charytatywnej, opowiadała, jak walczyła o to, by pytanie o stosunek do przyjmowania uchodźców padło podczas debaty telewizyjnej między kandydatami na urząd prezydenta RP. Podobnie jak Mikołajewski trzy lata wcześniej, chciała, by Polacy dowiedzieli się o tym, co dzieje się każdego dnia w basenie Morza Śródziemnego, wierząc, że jeśli tylko o tym usłyszą - nie pozostaną obojętni. Kiedy osiem miesięcy później przytoczyłem tę historię podczas innej debaty poświęconej społecznemu nastawieniu wobec uchodźców ${ }^{8}$, reakcją było zdziwienie porównywalne z tym, jakie jeszcze rok wcześniej towarzyszyło komentarzom mówiącym o strzelaniu do łodzi (teraz już uznanym za właściwie standardową reakcję na wszelakie doniesienia o kryzysie migracyjnym). Czas, w którym można było marzyć o tym, by społeczeństwo dowiedziało się o tragicznej sytuacji uchodźców, odszedł do prehistorii. Przekonanie, że reakcją na tę informację będzie odruch etycznej odpowiedzialności, okazało się boleśnie i kompromitująco naiwne.

Podczas spotkania w Centrum Sztuki Współczesnej mieliśmy świeże wspomnienia z manifestacji, która odbyła się na warszawskim Placu Zamkowym pod hasłem

\footnotetext{
7 „Konflikt i przemoc w Sieci mają oczywiście inny charakter niż in real life. Tę odmienność konstytuuje przede wszystkim wiara użytkowników w anonimowość tej formy komunikacji i związany z nią brak poczucia fizycznego zagrożenia”. M. Kamińska, Konflikt, przemoc, prowokacja w cyberkulturze, w: tejże, Niecne memy. Dwanaście wykładów o kulturze Internetu, Poznań 2011, s. 20.

8 Dyskusja odbyła się 12 lutego 2016 roku w Centrum Sztuki Współczesnej Zamek Ujazdowski i towarzyszyła wystawie oraz publikacji książki Anny Kubik W tym samym mieście, pod tym samym niebem...
} 
„Przeciw islamizacji Europy”. Półtoratysięczny - według szacunków policji - tłum protestował przeciwko „fali najazdu emigrantów z obcych kręgów kulturowych”" i planom przyjmowania ich przez państwa Unii. „Chcemy, żeby Polska pozostała Polską, aby w Polsce nie było islamskich dzielnic, nie dochodziło do rabunków, gwałtów, napadów, morderstw” - mówił jeden z organizatorów manifestacji. „Jako naród polski mamy prawo mówić, czy chcemy islamskich imigrantów, czy nie. My mówimy, że nie chcemy. Koniec" - dodawał inny ${ }^{10}$.

To, co wydarzyło się w tak zwanym międzyczasie - przejście od przekonania, że „jeśli tylko się dowiedzą - pomogą”, do wyśpiewywanego publicznie, na melodię refrenu Karuzeli Marii Koterbskiej, hasła „cała Polska śpiewa z nami, wyp...ać z uchodźcami” - można przedstawić chociażby na poziomie języka. Słowo „uchodźca” przeszło transformację semantyczną ${ }^{11}$ i przestało oznaczać „,osobę, która na skutek uzasadnionej obawy przed prześladowaniem z powodu swej rasy, religii, narodowości, przynależności do określonej grupy społecznej lub z powodu przekonań politycznych przebywa poza granicami państwa, którego jest obywatelem” "2 , zaczęło być natomiast stosowane jako synonim terrorysty, darmozjada, zboczeńca seksualnego. Ogólnie rzecz ujmując - z denotacji realnej ofiary przeszło $w$ konotację zagrożenia (na wielu poziomach: ekonomicznym, kulturowym, cywilizacyjnym, zdrowotnym) i potencjalnego oprawcy (gwałty, przemoc, ataki terrorystyczne). W jednej ze swych ostatnich prac Zygmunt Bauman pisał w tym kontekście o ,adiaforyzacji problemu migracyjnego (czyli wyłączeniu migrantów i tego, co się z nimi dzieje, z moralnej oceny). Gdy opinia publiczna już raz ich zakwalifikuje jako potencjalnych terrorystów, migranci trafiają

9 http://www.pap.pl/aktualnosci/news,466120,w-warszawie-odbyla-sie-manifestacja-przeciw-islamizacjieuropy.html [dostęp: 16.12.2016].

10

1 Zob. K. Kucharska, Leksem 'uchodźca’ w języku polskim, (niepublikowana praca magisterska napisana pod kierunkiem prof. K. Kłosińskiej na Uniwersytecie Warszawskim), Warszawa 2016. Na pytanie, jak to jest możliwe, odpowiedzi udzielić może Ludwik Wittgenstein, który w swojej koncepcji „gier językowych” wskazywał, iż znaczenia wyrazów kształtują się poprzez praktyki ich używania. Czerpiący z jego dorobku przedstawiciele brytyjskich culture studies utrzymywali, że podstawowe pole walk kulturowych dotyczy właśnie znaczenia znaku, władza opiera się natomiast na zdolności kształtowania znaczeń i wyobrażeń w umysłach obywateli/poddanych (w czym z kolei widać inspirację marksistowskimi koncepcjami Antonio Gramsciego). Zob. w tym kontekście również wywiad z artystką Janą Shostak, która postuluje zastąpienie „stygmatyzującego” i posiadającego „pejoratywny wydźwięk” określenia „uchodźca” - pojęciem „,nowak”; http://wiadomosci.radiozet.pl/Polska/Artystka-walczy-o-to-by-uchodzcow-zastapic-slowem-nowacy-WYWIAD [dostęp: 9.06.2017 r.].

Art. 1A ust. 2 Konwencji Genewskiej z 1951 roku. Krytykę takiego zdefiniowania uchodźcy, które ponadczasowy los prześladowanych relatywizuje do historycznie określonej koncepcji państw narodowych, przedstawia Giorgio Agamben w tekście My, uchodźcy, zob. http://recyklingidei.pl/agamben-my-uchodzcy [dostęp: 11.12.2016 r.]. W niniejszym tekście będę konsekwentnie używał określenia „uchodźcy”. Wynika to z „politycznych”, performatywnych (zgodnie z ujęciem J. Butler) przesłanek skoro internetowy i społeczny hejt wymierzony jest właśnie przeciw „uchodźcom”, ja próbuję w swoim tekście potraktować to określenie jako pole walki, odbierając mu negatywne konotacje, w jakie obrosło w ciągu ostatnich dwóch lat. 
poza granice i zasięg moralnej odpowiedzialności - oraz, przede wszystkim, poza przestrzeń współczucia” ${ }^{13}$.

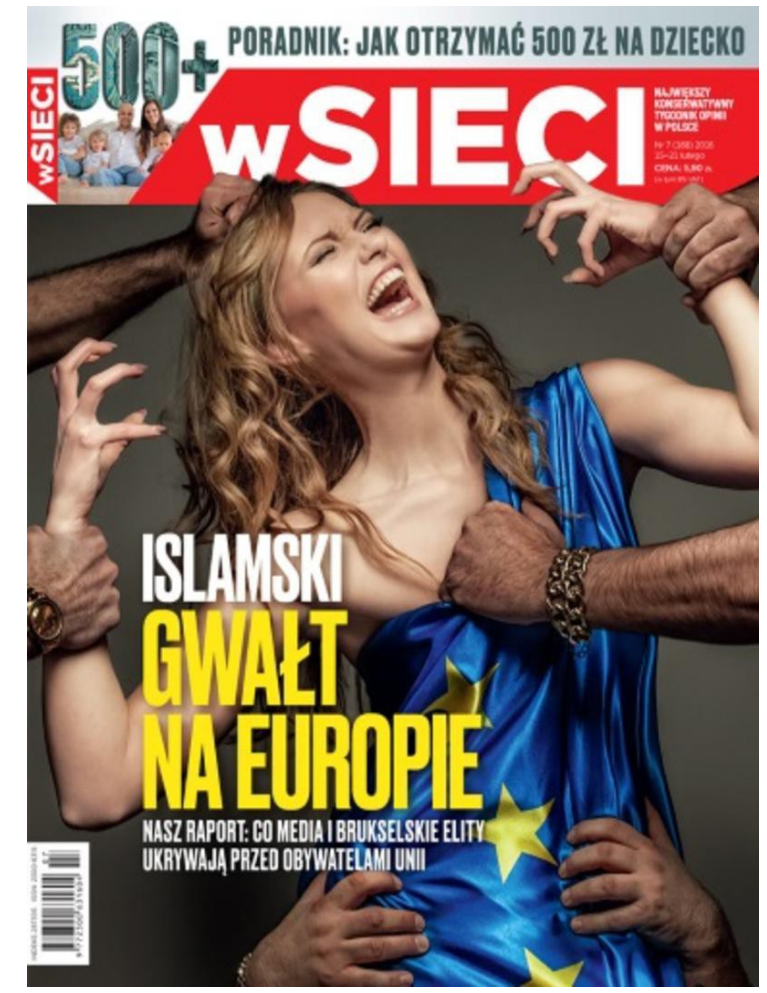

\section{1. Okładka tygodnika „WSieci” z 15 lutego 2016 roku}

Kolejna zmiana dotyczyła ubogacenia kulturowego - określenia powtarzanego jak mantra przez wielu teoretyków międzykulturowości jako tożsamościowa i poznawcza korzyść płynąca ze spotkania z Innym. Po napaściach na tle seksualnym, jakie miały miejsce podczas sylwestrowej nocy przełomu 2015 i 2016 roku Niemczech, uległo ono w dyskursie publicznym ironicznemu ośmieszeniu i - pisane zazwyczaj w cudzysłowie zaczęło odnosić się do gwałtów i aktów przemocy, które grożą europejskim kobietom ze strony wszelakich obcych przebywających i przybywających na ich terytorium (sympto-

13 Z. Bauman, Obcy u naszych drzwi, przeł. W. Micner, Warszawa 2016, s. 43. W dalszej części eseju Bauman pisze o sposobach radzenia sobie $\mathrm{z}$ dysonansem poznawczym między społecznym przekonaniem o własnym nieskalanym statusie moralnym a formułowanymi opiniami na temat migrantów: ,strategia ta przybiera formę przypisywania kategoriom ludzi wyłączonym spod naszej (poza tym bezwarunkowej) moralnej odpowiedzialności cech, które ich zniesławiają, prezentują jako niegodnych uwagi i szacunku. Tym samym pogarda i brak troski zostają usprawiedliwione, stanowią bowiem zasłużoną karę za nieuleczalne skazy lub złe intencje tych, których poniżyliśmy, zignorowaliśmy, potraktowaliśmy surowo czy w sposób rażący zaniedbaliśmy” (tamże, s. 94-95). 
matyczna w tym aspekcie była okładka tygodnika „W Sieci” z 15 lutego 2016 roku przedstawiająca białą kobietę rozszarpywaną przez hordę „islamistów”, sprowadzonych wyłącznie do dłoni-macek, subtelna sugestia - na nadgarstkach rąk o wyraźnie ciemniejszym odcieniu skóry znajdują się złote bransoletki i drogie zegarki).

Kolejnym słowem, które co prawda nie zmieniło swojego znaczenia, ale poprzez praktyki jego użycia uwydatniło rozbieżność między refleksją teoretyczną a praktyką społeczną, była „asymilacja”. Strategia ta, głęboko już skompromitowana wśród teoretyków międzykulturowości ${ }^{14} \mathrm{i}$ zastępowana przeważnie wielopoziomowo rozumianą integracją ${ }^{15}$, pojawiała się w dyskursie publicznym jako oczekiwany przez społeczność przyjmującą stan, do którego winni dążyć przybysze. Stąd też tworzenie apriorycznych podziałów na tych, którzy „chcą”, i tych, którzy „nie chcą” się asymilować, tudzież „łatwo” i „trudno” się asymilujących (wraz z bezkrytycznie przyjmowanym założeniem, że osoby o tożsamej religii czy denominacji należeć muszą ex definitione do „chcących” i „łatwo się asymilujących”). Kategoria asymilacji pojawiła się też we wspomnianym na początku niniejszego tekstu facebookowym wpisie, który stanowił zarzewie nie tylko „flejmu" między różnymi stronami stopniowo angażującymi się w całą sprawę, ale i wylewu hejtu skierowanego przede wszystkim w stronę uchodźców.

\section{Polska Mariuszem narodów - zarys (węższego) kontekstu}

Mariusz Pudzianowski, polski sportowiec - niegdyś strongman, a od pewnego czasu zawodnik mieszanych sztuk walki (MMA), prywatnie: właściciel firmy spedycyjnej - 21 stycznia 2016 roku umieścił na swoim fanpage’u zdjęcie przedstawiające kij baseballowy z podpisem „ZZ tym będę czekał na naczepie do UK przed wjazdem na port z Calais [...]. Na naczepie będzie przyspieszona nauka asymilacji”. Popularny „Pudzian” od pewnego czasu donosił już na Facebooku o problemach, jakie napotykają kierowcy z jego firmy podczas przeprawy przez kanał La Manche ze strony uchodźców zgromadzonych w obozie przejściowym, tak zwanej „dżungli” w Calais (napady, zastraszanie kierowców, włamania do przyczep), jednakże to dopiero wpis zilustrowany zdjęciem kija baseballowego nadał sprawie zawrotne tempo i rozgłos. Właściwie nie sam wpis, tylko reakcja Joanny Grabarczyk, działaczki związanej z inicjatywą HejtStop, zajmującą się przeciwdziałaniem mowie nienawiści w przestrzeni publicznej, która postanowiła zgłosić wpis sportowca do prokuratury jako naruszający art. 256, par. 1 Kodeksu Karnego mówiący o „nawoływaniu do nienawiści na tle różnic narodowościowych, etnicznych, rasowych, wyznaniowych”.

Na kontratak nie trzeba było długo czekać. Szóstego lutego Mariusz Pudzianowski opublikował wpis o następującej treści: „Skierowaliście w moją stronę topór wojen-

14 Zob. np. Z. Bauman, Studium przypadku z zakresu socjologii asymilacji: w pułapce wieloznaczności, w: tegoż, Wieloznaczność nowoczesna, nowoczesność wieloznaczna, Warszawa 1995.

Zob. M. Biernath, Różnorodność integracji - jej wymiary i mechanizmy, w: Problemy integracji imigrantów: koncepcje, badania, polityki, red. A. Grzymała-Kazłowska, S. Łodziński, Warszawa 2008. Autorka wymienia następujące poziomy integracji: 1. prawno-instytucjonalny, 2. ekonomiczny, 3. społeczny, 4. tożsamościowy, 5. kulturowy, 6. przestrzenny. Strategie te są w dużej mierze odpowiedzią na nie do końca udane projekty integracyjne, np. we Francji. 
ny droga fundacjo, ale moja artyleria w postaci Narodu Polskiego jest o wiele cięższa”, dodając do tego średnio subtelne aluzje do wyglądu fizycznego działaczki. Do „wymiany zdań” włączył się też muzyk i poseł Paweł Kukiz, który - również na Facebooku napisał: „Nie dziwię się pani Joannie... Gdybym był na jej miejscu [w domyśle: gdybym wyglądał tak jak ona - przyp. P.J.], też marzyłbym (marzyłabym) o imigrantach w kontekście sylwestrowej nocy [emotikon: uśmieszek]”. Wpis ten został kilka dni później usunięty przez P. Kukiza, natomiast sam poseł tłumaczył się, iż nie zamierzał „urazić uczuć” Joanny Grabarczyk, zakładał tylko, „że jej otwartość i tolerancja nie znają granic rasowych”. Internauci również ze swojej strony dali wyraz opiniom na całą tę sprawę, tworząc memy, w których nazywali działaczkę HejtStopu „donosicielem”, „kapusiem” czy „zdrajcą” (przy okazji pojawiały się też wyraźnie antysemickie określenia.

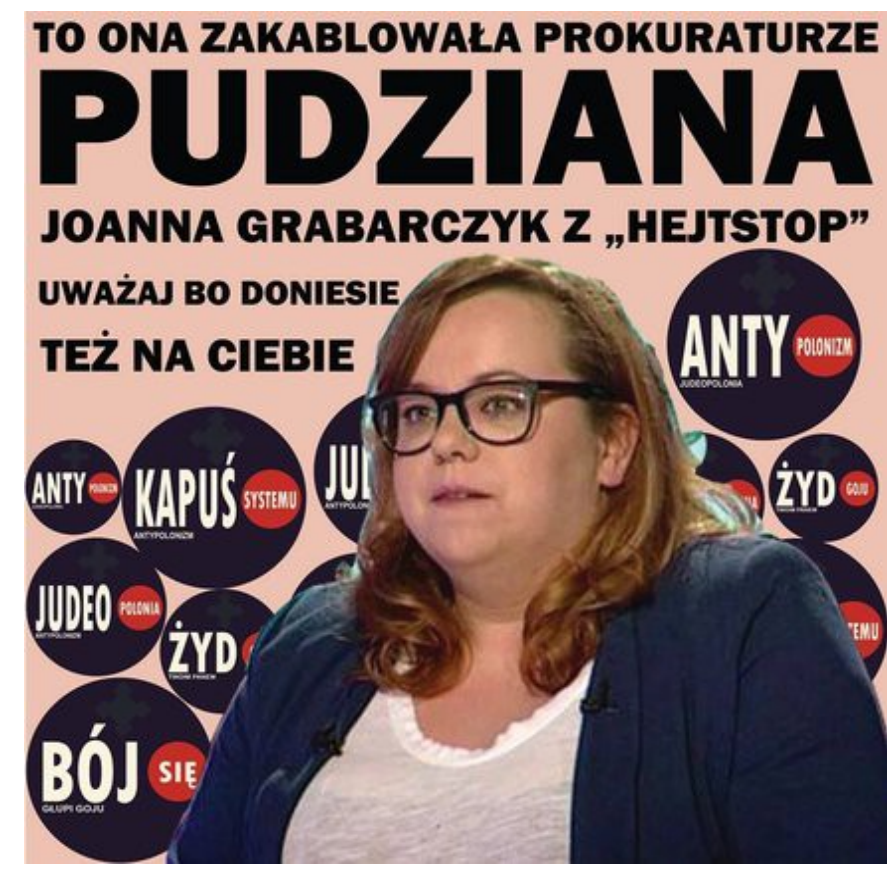

I1. 2. Jeden z memów komentujących zawiadomienie przez Joannę Grabarczyk prokuraturyo możliwości popełnienia przestępstwa przez Mariusza Pudzianowskiego ${ }^{16}$

Kiedy pod koniec lutego 2016 roku prokuratura odmówiła wszczęcia śledztwa przeciw Pudzianowskiemu - tym samym stwierdzając, że jego wpis nie nosił znamion czynu zabronionego - sprzyjający sportowcowi internauci obwieścili wielki triumf prawdy nad ,terrorem poprawności politycznej” (to kolejne słowo, które zmieniło swoje znaczenie i dziś konotuje raczej cenzurę, zamykanie ust siłą, nie zaś elementarną dawkę przyzwoitości i szacunku dla drugiego człowieka, regulującą dyskurs publiczny).

16 Źródło: http://kosikosi.salon24.pl/695249,mariusz-pudzianowski-antysemita [dostęp: 27.12.2016] 
Wcześniej jednak, piątego lutego, na dzień przed „wypowiedzeniem wojny” inicjatywie HejtStop i Joannie Grabarczyk, na fanpage’ach zarówno Pudzianowskiego, jak i jego firmy transportowej sportowiec opublikował dwanaście zdjęć, które w zamierzeniu miały przedstawiać coś w rodzaju materiału dowodowego potwierdzającego zasadność wpisu zilustrowanego kijem baseballowym. Było to jakby „fotostory” opowiadające wizualnie o przyłapaniu kilku mężczyzn podczas próby nielegalnego przedostania się z Francji do Anglii w naczepie tira (dwie ilustracje przedstawiają ich „na gorącym uczynku” - siedzących w kartonach z towarem, całość przypomina natomiast jaką́s groteskową wersję zabawy w chowanego, co sugeruje zresztą podpis pod jednym ze zdjęć: „A kuku tu wlazłem do pudełka z papierosami hejj!! A co mam ochotę na Malboro!!” [pisownia oryginalna]).

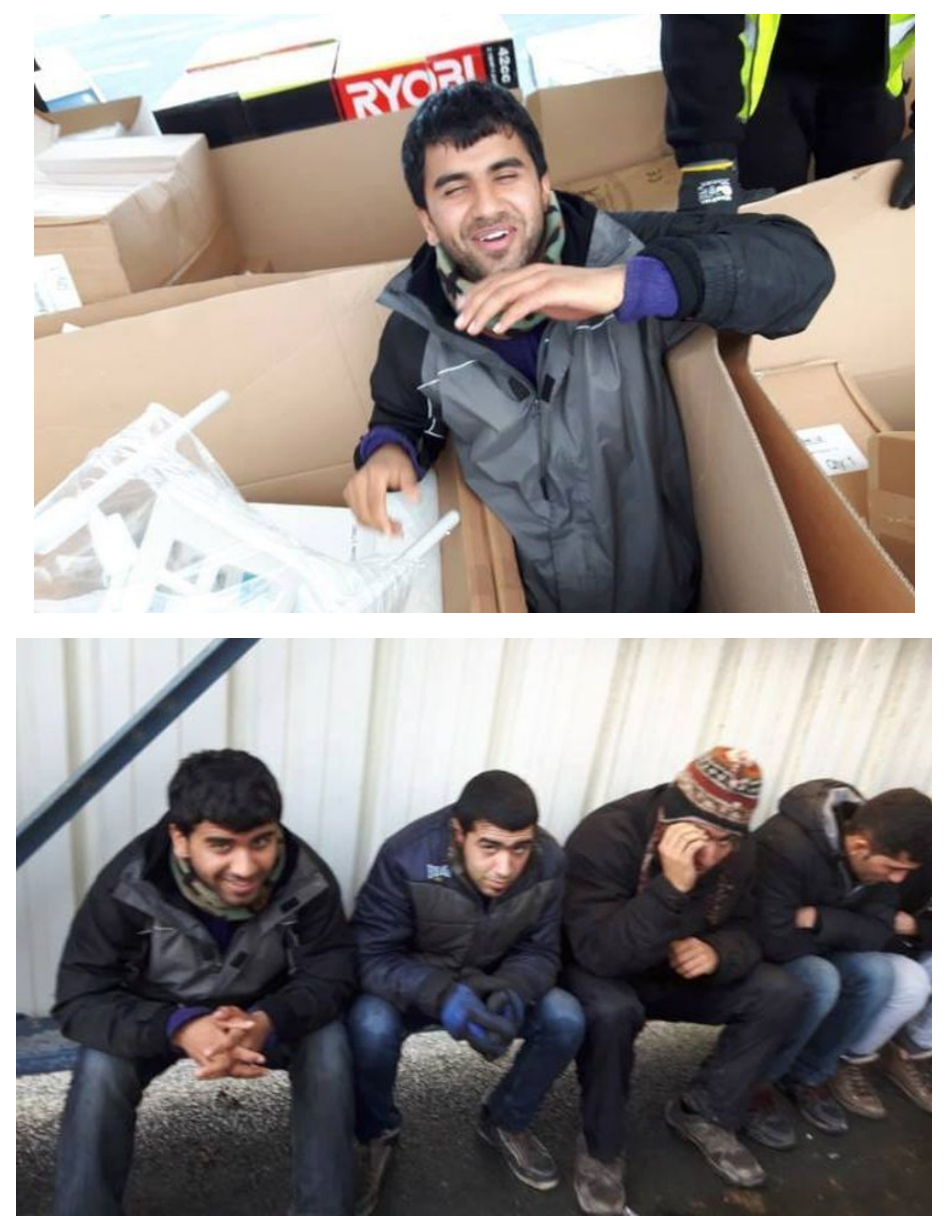

II. 3 i 4. Zdjęcia opublikowane na facebookowych fanpage’ach Mariusza Pudzianowskiego oraz jego firmy spedycyjnej 5 lutego 2016 roku $^{17}$

17 Źródło: http://topmejt.co.uk/pudzian-atakuje-hejtstop-i-publikuje-szokujace-zdjecia-z-calais/ [dostęp: 27.12.2016]. 
W niespełna tydzień wpis na fanpage’u firmy spedycyjnej osiągnął status: 38 tysięcy udostępnień, 60 tysięcy polubień (Facebook nie dawał jeszcze wówczas możliwości okazywania szerszej gamy emocji) oraz ponad 4200 komentarzy (stan na 12 lutego). Wśród tych komentarzy (a liczba ta obejmuje jedynie wpis jako taki, nie uwzględniając poszczególnych zdjęć z galerii, a także jego/ich udostępnień), odnotowałem - stosując niedoskonałą co prawda, ale dającą pewien obraz całości metodę wyszukiwania słów poprzez opcję przeglądarki - następującą liczbę występowania danych określeń: „brudasy” - 275, „ciapate/ty” - 158, „bydło” - 127, „ścierwo” - 75, „k...wy”, „s...syny” - 361, „za/wy/na/j...bać”- 325, „kozoj...cy” - 64, „gaz”, „do gazu”, „zagazować” - 105, „strzelać”, „,wy/roz/strzelać” - 140, „Adolf”, „Hitler”, „Oświęcim”, „Auschwitz” (w tonie afirmatywnym) - 62. Nie są to dane w sensie ścisłym, daleko im również do kompletności (nie sposób chociażby w żaden sposób określić ilości „hejtu” - jakiej miary mielibyśmy w ogóle użyć? - którą wygenerowało każde z ponad 38 tysięcy udostępnień). Jeśli nawet, na co liczę, są one w stanie jakoś naświetlić zarówno ilościowy, jak i jakościowy charakter tego zjawiska ${ }^{18}$, to $\mathrm{z}$ pewnością nie oddają doświadczeń osoby, która postanowiła uważnie je prześledzić (co poczuli ci, których bezpośrednio one dotyczyły, mogę sobie jedynie wyobrazić...). Przedzieranie się przez te komentarze było dla piszącego te słowa, by posłużyć się sformułowaniem Dariusza Czai, obcowaniem ze „stężeniem trucizn na potężną skalę”19 . „Nie wychodzi się z tej lektury nietkniętym, niepokaleczonym” - „z tej lektury naprawdę wychodzi się chorym" 20.

Zdecydowanie największą agresję wśród komentujących wywołały dwa zdjęcia, na których jeden z mężczyzn uśmiecha się w kierunku aparatu (il. 3 i 4). Ramy, w jakie wtłoczone zostały te przedstawienia - wyznaczone przez fotografię ukazującą kij baseballowy - sprawiły, że ich pogodno-ludyczny charakter (na pierwszym mężczyzna wydaje się wyraźnie ubawiony faktem, że jego kryjówka została odkryta; drugie przypomina jakby grupę niesfornych chłopców czekających w wymuszonym napięciu przed gabinetem dyrektora i wysyłających porozumiewawcze spojrzenie w stronę widzów) zupełnie

18 Przedstawianie tych wszystkich określeń wiąże się z poważnym problemem natury etycznej. Mówienie o mowie nienawiści zawsze niesie ryzyko, że jest jednoczesnym uobecnianiem tej mowy (dystans metajęzykowy nie zapewnia wystarczającej ochrony), że jakieś jej elementy pozostają, nawet gdy mówi się o niej, wbrew i przeciw niej, nie zaś „nią” czy „, jej wnętrza”. Jak stwierdza Judith Butler: „W przypadku mowy nienawiści wydaje się, że niemożliwa jest naprawa jej skutków inaczej niż poprzez intensyfikację jej obiegu, nawet jeśli odbywa się to w obrębie publicznego dyskursu wzywającego do objęcia jej cenzurą. [...] Bez względu na to, jak stanowczy jest sprzeciw wobec samej takiej mowy, jej powtarzania, nieuchronnie odtwarza się też samą traumę" (J. Butler, Walczące słowa. Mowa nienawiści i polityka performatywu, przeł. A. Ostolski, Warszawa 2010, s. 49). Mowa nienawiści jest zbyt ważna, by o niej milczeć, i zbyt bolesna/raniąca, by ją cytować (ale też - z tych samych przyczyn - by łagodzić ją aluzjami i subtelnościami). Nie można walczyć z nią tak, by jednocześnie w jakimś stopniu jej nie pobudzać. Jedyne, co pozostaje, to wiara, iż siła sprzeciwu zneutralizuje skutki tego pobudzenia. Stąd moja niezgoda na „pierwsze przykazanie” z Dekalogu antytrollingu autorstwa Eryka Mistewicza, sugerujące pewną formę biernej walki przez zaniechanie. Zob. https://wszystkoconajwazniejsze.pl/eryk-mistewicz-dekalog-antytrollingu/ [dostęp: 11.02.2017].

D. Czaja, Lekcje ciemności, Wołowiec 2009, s. 14.

Tamże, s. 88 i 199. 
zanikł, a całość została odebrana jako akt prowokacji, co dało komentującym asumpt to prezentowania mniej lub bardziej wymyślnych propozycji, jak tu sprawić, by osoby na zdjęciach „przestały się tak głupio cieszyć”. Ponownie nie przedstawię tu żadnych danych z analizy statystycznej sensu stricto, a jedynie moje wrażenia z obserwacji, chcąc nie chcąc, uczestniczącej: doprawdy nieliczne z owych ponad czterech tysięcy komentarzy pozbawione były jawnego elementu agresji i nienawiści (a i to najczęściej w przypadku wyrazów wsparcia bądź porad prawnych dla Pudzianowskiego, a więc w wypowiedziach utrzymanych w rejestrze zasadniczej zgody, którą odczytać można jako ciche przyzwolenie na ogólny ton „dyskusji”). Liczba osób nawołujących do opamiętania się oscylowała w granicach liczby sprawiedliwych w Sodomie.

Należy przy tym odnotować, że Pudzianowski już pod wpisem o „przyspieszonej nauce asymilacji” umieścił informację, iż „wszystkie komentarze z mięsem i zbędnymi określeniami będą usuwane”, w późniejszym wpisie natomiast - z 19 lutego - dodał post scriptum o treści: „Proszę o kulturalne komentarze. Wiem, że każdy jest zdenerwowany tą sytuacją, ale zachowajmy poziom! Nie dajmy się sprowokować, ponieważ prawo oraz pojęcie hejtu zostały tak skonstruowane, aby nas zastraszyć. Nie będziemy siedzieć cicho, ale też trzymajmy poziom”21. Tym samym sportowiec „umywał ręce” od odpowiedzialności za wpisy i komentarze pojawiające się na jego fanpage’ach. Jedyne, co można mu zarzucić, to „grzech zaniechania” - opieszałość przy usuwaniu „komentarzy z mięsem i zbędnymi określeniami”. Wobec ich zalewu nie może dziwić fakt, że ostatecznie kilka tygodni później administratorzy stron zdecydowali się na hurtowe usunięcie wpisów i zdjęć. Była to opcja bardziej ekonomiczna niż przeczesywanie tysięcy wypowiedzi i usuwanie tych nacechowanych nienawiścią i agresją (a więc, w moim odczuciu, zdecydowanej większości z nich), obecną na wielu płaszczyznach: począwszy od wulgaryzmów i stygmatyzujących określeń, poprzez nawoływanie wprost do aktów przemocy (z sugestiami metod unicestwienia włącznie), niby-żarciki na tle rasowym bądź religijnym (,a gdyby tak wysmarować przyczepę świńską krwią”), na komentarzach typu „Adolf by zrobił z nimi porządek” lub „do Oświęcimia z nimi” skończywszy.

Jeśli z omawianego przypadku płynie jakaś wartość poznawcza, to z pewnością jest to konieczność ponownego przemyślenia pewnych wygodnych i obiegowych przekonań dotyczących internetowego hejtu:

1. Anonimowość zapewne sprzyja mowie nienawiści, ale jej brak bynajmniej nie powstrzymuje użytkowników przed formułowaniem najbardziej nawet haniebnych - $\mathrm{z}$ etycznego punktu widzenia - $\mathrm{i}$ trudnych do wyobrażenia $-\mathrm{w}$ ramach respektowania pewnych standardów kultury - wypowiedzi.

2. Analogicznie w przypadku poczucia bezkarności i nikłego ryzyka jakichkolwiek sankcji (społecznych, prawnych) - może i sprzyjają one hejtowi, ale nawet realna

21 Dodajmy, że był to komentarz do udostępnionego na fanpage’u firmy transportowej Pudzianowskiego memu internetowego, na którym informacja o karze 800 zł grzywny dla mieszkanki Lublina za obraźliwe uwagi w stronę syryjskich uchodźców skwitowana została sformułowaniem: „„Poprawność polityczna« rodem z zachodu zawitała do Polski. Naszywasz bandytę bandytą? Uważaj jaki ma kolor skóry bo jeśli inny niż biały zostaniesz ukarany za sianie mowy nienawiści i rasizm” [pisownia oryginalna]. 
perspektywa negatywnych reperkusji (blokady na Facebooku, zgłoszenia do prokuratury) nie ma mocy powstrzymania użytkowników przed jego szerzeniem. Co więcej, paradoksalnie, korzystanie z narzędzi do przeciwdziałania mowie nienawiści (zgłoszenia administratorom portali lub państwowym organom ścigania) może przynosić efekty odwrotne do zamierzonych: dodatkowo rozjątrzyć hejterów i skłaniać ich do przyjmowania pewnej formy etosu bohaterskiego (,,a niech mnie zgłoszą, ale i tak napiszę to, co wszyscy myślimy!”) w imię walki przeciw zredefiniowanej „poprawności politycznej”.

3. Hejterami mogą być wszyscy - zarówno zblazowana „gimbaza”, jak i dorośli obu płci, w różnym wieku, z różnych klas społecznych. Hejterzy to po prostu „ludzie tacy jak my" - uśmiechnięci rodzice tulący swoje pociechy, zmysłowe kobiety pozujące do romantycznych sesji, uduchowieni artyści palący papierosy w tajemniczym półmroku, młodzi freelanserzy popijający kawę w popularnych sieciówkach nad otwartym „makiem”22 „ZWwyczajne (normalne) od monstrualnego oddziela cienka ścianka”23.

\section{Figury wyobraźni prześladowczej}

W swych wnikliwych analizach zawartych w pracy Walczące słowa Judith Butler dokonuje podwójnego gestu wobec podmiotu głoszącego mowę nienawiści: z jednej strony ogranicza jego/jej sprawczość i uwalnia go/ją od zarzutu o bycie źródłem/przyczyną owej mowy oraz przenoszonej przez nią nienawiści ( hate speech, tak jak każdy performatyw w rozumieniu J.L. Austina, oparty jest na iterowalności i czerpie swą moc sprawczą ze społecznych rytuałów i konwencji; tym samym osoba głosząca mowę nienawiści zawsze jedynie „cytuje”, aktualizując dyskurs ją poprzedzający ${ }^{24}$ ), z drugiej zaś - i właśnie dlatego - stawia jej/jemu zarzut o wiele cięższy odpowiedzialności za wszystkie wcześniejsze konteksty, które zostają przywołane w owym akcie cytowania/aktualizacji. Jak pisze Butler: „ktokolwiek posługuje się mową nienawiści, bierze na siebie odpowiedzialność za sposób, w jaki jest powtarza-

22 To nie są teoretyczne, ani tym bardziej „poetyckie” typy, to opis raptem kilku z kilku tysięcy realnych przypadków. Szczególny dysonans poznawczy pojawiał się przy - wcale nie aż tak rzadkich - sytuacjach, kiedy pełna nienawiści treść sygnowana była zdjęciem profilowym, na którym znajdowało się dziecko hejtującej osoby.

D. Czaja, dz. cyt., s. 158.

W przypadku ostatnich komentarzy pod wpisem Pudzianowskiego - ich pozycja wynikała z algorytmu porządkowania treści, nie z daty wstawienia - owo cytowanie widoczne było jak na dłoni: nieznośnie długi ciąg wpisów ograniczających się do: „do gazu ich”, „rozstrzelać” itp. Zgodnie z ujęciem Butler, byłoby to cytowanie stwierdzeń, które same w sobie są już cytatami, cytowanie drugiego stopnia czy „metacytowanie”. Diachroniczna, segmentowa struktura interfejsu Facebooka jedynie maskuje fakt, że był to tak naprawdę odpowiednik skandowania - symultanicznej, opartej na sile mimetyzmu wypowiedzi rozpalonego emocjami tłumu (bardziej wyraźne jest to w przypadku „lajkowania” owych stwierdzeń, które jest niejako komunikatem: „też tak uważam / mówię to samo”). Tłum z kolei swą moc i sankcję czerpie również z tego, że „cytuje” inne tłumy, odtwarza wcześniejsze konteksty publicznego spektaklu niezgody i zapalczywości. 
na, za jej ożywianie, za odtwarzanie kontekstów nienawiści i krzywdy. Odpowiedzialność mówiącego nie wynika z tego, że tworzy język ex nihilo, lecz raczej z faktu negocjowania spuścizny języka" ${ }^{25}$.

W komentarzach pod wpisem Mariusza Pudzianowskiego, które są jedynie małym wyimkiem społecznych reakcji na tzw. problem migracyjny, mieliśmy do czynienia z „ożywieniem” i „odtworzeniem” kontekstu prześladowań, linczów i eksterminacji, z aktualizacją (,zacytowaniem”) archaicznych struktur kolektywnej przemocy ${ }^{26}$. Typologia i charakterystyka występujących w ich ramach figur myślowych jest dziełem wspomnianego na wstępie René Girarda, zdaniem którego „wyobraźnia prześladowcza” posługuje się czterema stereotypami, obecnymi już w „mitach założycielskich” wszelkich systemów mitologicznych, a następnie ożywianymi w praktykach dyskryminacji i przemocy wobec czarownic, Żydów, jak i innych mniejszości etnicznych, religijnych czy społecznych, czynionych na przestrzeni dziejów w imię „oczyszczania wspólnoty”. Do stereotypów owych należą: (1) społeczny i kulturowy kryzys przedstawiany jako „odróżno-

25 J. Butler, dz. cyt., s. 38. Dalej filozofka pisze, iż: „raniące nazwy mają swoją historię, którą przywołuje i utrwala się w momencie wypowiedzi, ale bez jej otwartego opowiadania. Nie chodzi tylko o to, jak te słowa były w przeszłości używane, w jakich kontekstach i dla jakich celów. Mowa o sposobie, w jaki owe historie są zatopione i zatrzymane w danej nazwie i poprzez nią" (tamże, s. 47). Dodać należy, odnosząc się do omawianego przypadku, że bezpośrednie odwoływanie się do obozów koncentracyjnych i wszelakich metod masowych egzekucji jest tu „otwartym opowiadaniem” historii zawartych w tych słowach.

26 Pozwolę sobie w tym miejscu odnotować pewną problematyczność polskich regulacji prawnych w odnośnym zakresie. Sformułowanie „nawoływać do nienawiści” (art. $256 \mathrm{KK}$ ) jest semantycznie nieprecyzyjne i zakresowo niedookreślone (zob. ekspertyzę prawniczki Karoliny Kudyby, obejmującą językową analizę tego artykułu oraz interpretację historii orzecznictwa: www.otwarta.org/wpcontent/uploads/2015/08/Ekspertyza-prawna-dot.-nawo\%C5\%82ywania-do-nienawi\%C5\%9Bci-K.Kudyba.pdf [dostęp: 11.02.2017]). Zgodnie z „,literą” przepisu, penalizowane jest wyłącznie „nakłanianie” innych do tego, by żywili „uczucie silnej niechęci, wrogości wobec kogoś” (słownikowa definicja „nienawiści”), przeoczony zostaje natomiast fakt, że - po pierwsze - owo „nawoływanie” samo w sobie jest aktem nienawiści (aspekt illokucyjny), po drugie - że jego konsekwencje (aspekt perlokucyjny) nie muszą ograniczać się do tego, że ktoś coś poczuje (w tym wypadku: nienawiść), ale owocować mogą konkretnymi i realnymi aktami przemocy (ten zakres obejmuje $\$ 2$ art. 255: „Kto publicznie nawołuje do popełnienia zbrodni, podlega karze pozbawienia wolności do lat 3 ”). Wreszcie, przepis ten nie uwzględnia perspektywy drugiej strony - tej, która jest obiektem nienawiści (art. 216 KK, ustalający zakres przypadków podpadających pod „znieważenie osoby”, odnosi się właśnie do konkretnej, pojedynczej osoby, nie grupy czy wspólnoty, nie jest więc relewantny w omawianej sytuacji, podobnie zresztą jak art. 190 mówiący o „groźbie karalnej”, gdzie również pojawia się „inna osoba” i konkretny „pokrzywdzony” w liczbie pojedynczej). Pamiętać przy tym należy, że prawo jest bronią obosieczną, o czym przekonuje wpis jednego z internetowych komentatorów „kazusu Pudziana”: „Panie Mariuszu, każdy średnio rozgarnięty prawnik udowodni, że nie nawołuje Pan do przemocy, ale zapowiada obronę swego mienia. Gwarantuje to Panu prawo polskie oraz międzynarodowe. Proponuję skierować wobec tej szkodliwej kobiety [Joanny Grabarczyk - przyp. P.J.] pozew cywilny, dotyczący naruszenia pańskiego dobrego imienia. Należy tez złożyć doniesienie do prokuratury mówiące o propagowaniu przez tę panią zuchwałego rozboju, kradzieży, niszczenia mienia oraz powodowania zagrożenia w ruchu drogowym" (komentarz pod: http://pressmania.pl/pudzianowski-w-prokuraturze-zapowiada-tanio-skory-nie-sprzedam-hejtstop/ [dostęp: 11.02.2017]). 
rodnienie” [indifférencation]; (2) opis „zbrodni odróżnorodniających”; (3) znaki selekcji ofiarniczej ${ }^{27}$, (4) sama przemoc.

Stereotyp pierwszy wiąże się z pewną diagnozą aktualnego stanu społeczno-kulturowego, którego konstytutywne struktury i hierarchie miałyby ulegać destrukcyjnemu zatarciu (przykładem jest tu chociażby motyw danse macabre - alegoria epidemii, śmierci-choroby jako osobowej siły sprawczej, która pochłania życia wszystkich ludzi, nie zważając na podziały społeczne i stanowe). W aktualnych realiach stereotyp ten objawia się pod postacią metanarracji o zagrożeniu cywilizacyjnym i kulturowym, która oparta jest na imperialistycznych wykładniach schematu „my” - „oni” ${ }^{28}$. Kolonizacyjna inwazja „islamu” ${ }^{29}$ grozi „nam” - przedstawicielom judeochrześcijańskiej cywilizacji zachodniej - roztopieniem się w homogenicznej masie, w której obowiązywać będą „ich” zasady, uważane obecnie przez „nas” za barbarzyńskie. Co gorsza, to już się dzieje: z przestrzeni publicznej usuwane są dystynktywne znaki naszej tożsamości kulturowej (w jakimś duńskim miasteczku rada zakazała postawienia choinki na święta) i zastępowane znakami obcymi (meczety, turbany, hidżaby).

Stereotyp działa zatem w ten sposób, że pełne pogardy odróżnorodnienie, które „im” przypisujemy (odróżnorodnienie charakterystyczne, co ważne, dla zwierzęcych, nie-ludzkich form zbiorowych, stąd określenia typu „bydło”, „szczury”, „stonka”, „szarańcza”), miałoby być albo „ich” docelowym postulatem, który wdrażać będą za pomocą hegemonistycznych decyzji stopniowo przejmowanej od „nas” władzy, albo też miałoby być „zaraźliwe”, w na poły tylko metaforycznym sensie. Uchodźcy bowiem nie tylko przenoszą „różnego rodzaju pasożyty i pierwotniaki” ${ }^{30}$ (intuicja ta zawarta jest w określeniu „szczury”), nie tylko sieją zniszczenie (jak stonki oraz - bardziej zmitologizowana - szarańcza), ale też - w wielu komentarzach - oni są „pasożytami” czy nawet samą „zarazą”.

W przywołanych powyżej określeniach zawierają się dwa Girardowskie stereotypy zarówno samo odróżnorodnienie (jako cecha „im” przypisywana, będąca jednocześnie zagrożeniem dla „nas”), jak i zbrodnia odróżnorodniająca (na poły biologiczne, na poły mi-

27 W bardziej zeświecczonym, socjologicznym języku można określić je - za Ervingiem Goffmanem - jako symbole piętna (zob. E. Goffman, Piętno. Rozważania o zranionej tożsamości, przeł. A. Dzierżyńska, J. Tokarska-Bakir, Gdańsk 2007).

W dalszej części tekstu będę pisać „my” i „oni” (w cudzysłowie) nie po to, by dokonywać jakiejkolwiek ekstrapolacji czy generalizacji, ale by zaznaczyć pozycje wydzielane przez kolonialny dyskurs.

Cudzysłów wynika z faktu, że jest to islam odpowiednio przez „nas” spreparowany, o czym przekonują autorzy raportu Obserwatorium Debaty Publicznej „Kultury Liberalnej” zatytułowanego Negatywny obraz muzułmanów w polskiej prasie. Analiza wybranych przykładów z lat 2015-2016; zob. https://www.rpo.gov.pl/sites/default/files/Raport\%20Negatywny\%20obraz\%20muzu\%C5\%82man \%C3\%B3w\%20w\%20polskiej\%20prasie.\%20Analiza\%20wybranych\%20przyk\%C5\%82ad\%C3\%B3w\%20z\%201at \%202015-2016.pdf [dostęp: 11.02.2017]. 12.02.2017]. 
tyczne „zarażanie”) $)^{31}$ - a implicytnie przywołana wizja epidemii zazębia się z symboliką nieczystości i skazy ${ }^{32}$. (Przypomnę, że mechanizm kozła ofiarnego służy właśnie „oczyszczeniu wspólnoty z elementów nieczystych”). W pojedynczych „raniących słowach” skumulowana jest cała dziejowość (określana przez Butler jako „historia, która się w nią [nazwę - przyp. P.J.] wtopiła, zyskując decydujący wpływ na jej współczesne znaczenie" ${ }^{33}$ ) konglomerat splecionych dyskursów i wyobrażeń kolonialnych ${ }^{34}$, historycznych (wielkie epidemie), mitologicznych (skalanie, nieczystość), politycznych (inwazja) i biologicznych, operujących zarówno na poziomie dosłownym, jak i metaforyczno-fantasmagorycznym (do tego stopnia, że czasami nie sposób analitycznie ich rozdzielić).

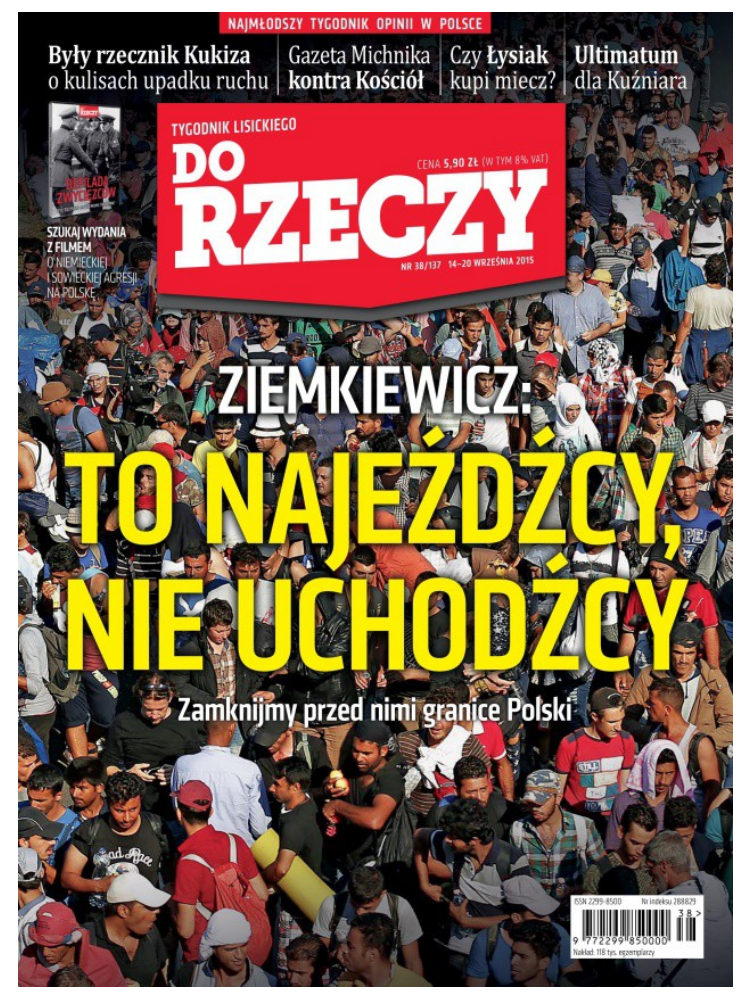

II. 5. Inwazja masy. Okładka tygodnika „Do Rzeczy” z 14 września 2015 r.

31 Jednym z pierwszych omawianych przez Girarda przykładów mechanizmu kozła ofiarnego są prześladowania Żydów podczas czternastowiecznej epidemii dżumy, po tym jak obarczono ich winą o zatrucie wody.

32 Które są jednocześnie kategoriami symbolicznymi i moralnymi. Zob. P. Ricoeur, Symbolika zła, przeł.

S. Cichowicz, M. Ochab, Warszawa 2015; M. Douglas, Czystość i zmaza, przeł. M. Bucholc, Warszawa 2007.

33 J. Butler, dz. cyt., s. 47.

34 Jedna z komentujących - zakładam, że nie do końca świadomie - zacytowała prawie że wprost słowa Kurtza z Jądra ciemności Josepha Conrada: „Wytępić całe to bydło!”. 
Odróżnorodnieniu ulec może więc cały świat - świat, jaki znamy, świat, do jakiego przywykliśmy, „nasz” świat. Zagrożenie dotyczy bowiem nie tylko wyeliminowania konstytutywnego dla myślenia kolonialnego podziału na centrum (które jest „tu”) i peryferie (które są „,gdzieś tam”), ale także związanego z tym niebezpieczeństwa zniesienia „różnicy antropologicznej”, niestabilnej linii oddzielającej człowieka od zwierzęcia. Jedno i drugie odbyć by się miało poprzez roztopienie, stłamszenie „naszego” indywidualizmu, konstytutywnych odmienności i wszystkiego, co sankcjonuje „naszą” supremację, w przypisywanych „im” (tak uchodźcom, jak i zwierzętom) formach niezróżnicowanej wielości (roju, stadzie, fali, masie), czy to poprzez formy politycznej represji i terroru, czy poprzez - jakkolwiek rozumiane - „zarażanie”35.

Do stereotypu drugiego - zbrodni odróżnorodniających - oprócz omówionych powyżej oskarżeń o bycie zarzewiem epidemii, dołożyć należy jeszcze dwa - terroryzm oraz zbrodnie na tle seksualnym.

Ataki terrorystyczne mogą przywodzić na myśl epidemie (śmierć nie zważa na żadne podziały społeczne), ale też zasadniczo różnią się od nich nie tylko swoją nagłością i krótkotrwałością (są pojedynczym aktem albo serią aktów), ale przede wszystkim bezdyskusyjną możliwością wskazania osobowej siły sprawczej - terrorysty. O ile w przypadku epidemii, podobnie jak w procesach o czary, winnego/winną powoływała do życia „wyobraźnia prześladowcza” (a egzekwowanie prawdy za pomocą przesłuchania dostarczało dowodów pod postacią przyznania się do winy), za zamachami terrorystycznymi naprawdę stoją konkretni ludzie. Mechanizm kozła ofiarnego, w jego uproszczonym powszechnym rozumieniu, objawia się jednak i tu w całej pełni. Pojedynczy terrorysta kieruje bowiem uwagę w stronę swoich mocodawców, a ci są jedynie „oficjalną” reprezentacją szerszych i zasadniczo jednomyślnych sił i formacji ideowych, których celem jest zniszczenie „nas” wszelkimi dostępnymi środkami. Uchodźcy byliby zatem emisariuszami, świadomymi bądź nie, owych tajemnych sił, wysłanymi na ostateczne cywilizacyjne starcie. Stereotypowe utożsamienie uchodźca $=$ muzułmanin $=$ terrorysta, racjonalizowane czasami za pomocą formuły „nie każdy

35 Dodać należy, że między groźbą „odróżnorodnienia” a groźbą „skalania” nie zachodzi, jak mogłoby się na pierwszy rzut oka wydawać, sprzeczność. Wręcz przeciwnie - to dwa aspekty tego samego zagrożenia. Owa konstytutywna różnorodność zabezpieczona jest bowiem wizją pewnej nadrzędnej wobec nich płaszczyzny wspólnej, którą można ująć albo jako kultura (w rozumieniu proponowanym przez niemieckich filozofów przełomu XIX i XX wieku - jako współdzielone wartości i idee - i wyznaczanym głównie przez kryteria narodowe), albo - w rejestrze mityczno-wyobrażeniowym - właśnie jako „czystość” (czystość danej wspólnoty, ethnosu, narodu, kultury, cywilizacji - kategoria ta zachowuje swą moc niezależnie od stopnia abstrakcji). Arjun Appadurai określił to jako „lęk przed niezupełnością", bardzo łatwo przeradzający się w lek przed zamianą układu proporcji i sił między większością, która czuje się zagrożona, a mniejszością, która przedstawiana jest jako źródło owego zagrożenia, aż do wizji pełnego wchłonięcia większości przez mniejszość włącznie: „,małe liczby wzbudzają gniew [...], gdyż stanowią maleńką przeszkodę na drodze od większości do totalności czy totalnej czystości. W pewnym sensie im mniejsza liczba i im słabsza mniejszość, tym większy gniew o to, że większość czuje się zaledwie większością, nie zaś pełnym i niekwestionowalnym ethnosem” (A. Appadurai, Strach przed mniejszościami. Esej o geografii gniewu, przeł. M. Bucholc, Warszawa 2009, s. 59; kursywa moja - P.J.). 
muzułmanin to terrorysta, ale każdy terrorysta to muzułmanin" ${ }^{36}$, zakorzeniło się w opiniach społecznych.

W jednym z fragmentów Obcego u naszych drzwi Bauman wyraźnie opisuje mechanizm kozła ofiarnego (przerzucania winy za zjawiska, których rozumienie nam się wymyka, na konkretną grupę), choć nie nazywa go wprost: „[imigranci] informują nas i ciągle przypominają nam o [...] jakichś globalnych i odległych siłach, o których się słyszy, ale których się nie widuje. O siłach, które ciężko sobie wyobrazić, ale które są na tyle potężne, że oddziałują na nasze życie, nie zważając na nasze preferencje. W cywilnych ofiarach tych sił, zgodnie z jakąś wypaczoną logiką, widzi się pierwsze szeregi oddziałów wysłanych przez owe mroczne potęgi, stacjonujące teraz w naszym sąsiedztwie" 37 . Jest to logika na tyle wypaczona, na ile wypaczona jest każda logika kozła ofiarnego, nie mniej i nie bardziej. Jej „wypaczenie” polega na tym przede wszystkim, że w oczach tych, którzy ją stosują, jest w pełni „logiczna” (ale tak właśnie działa Girardowska „wyobraźnia prześladowcza”). Innymi słowy, jest to wypaczenie dostrzegalne przez tych, którzy - jak twierdzą - rozpoznali mechanizm, u tych, którzy - jak utrzymują ci pierwsi pozostają wjego władaniu (zapewne z perspektywy tych drugich perspektywa tych pierwszych jest również „wypaczona” - „ideologią multi-kulti”, „lewactwem” czy „liberalizmem").

Kolejna „zbrodnia odróżnorodniająca” ma charakter seksualny. Jedno z „raniących słów” używanych wobec uchodźców sugeruje, że utrzymują oni - tzn. mężczyźni ${ }^{38}$ stosunki seksualne z kozami. W tej trawestacji (genderowym odwróceniu) dawnego zarzutu stawianego czarownicom, które miałyby obcować cieleśnie z kozłem, sataniczny wymiar tego aktu zanika (choć czy zupełnie?) i zastąpiony zostaje ramami zboczenia, perwersji seksualnej ${ }^{39}$.

36 Nie zamierzam przy tym twierdzić, że „żaden uchodźca nie jest terrorystą”, ale tak samo nie będę utrzymywać, że żaden Polak, chrześcijanin, żaden student czy wykładowca akademicki nie jest lub nie może stać się terrorystą. Twierdzę jedynie, że między byciem terrorystą a byciem uchodźcą / Polakiem / chrześcijaninem / studentem / wykładowcą akademickim etc. nie zachodzi żadna znacząca korelacja. Z. Bauman, Obcy..., dz. cyt., s. 23.

By uzyskać pełniejszy obraz omawianego zagadnienia, strategie przedstawiania uchodźców należałoby ująć także z perspektywy genderowej, wykracza to jednak znacznie poza ramy niniejszego szkicu. Ograniczę się zatem do stwierdzenia, że jedną z konsekwencji semantycznego przekształcenia, jakiemu uległo określenie „uchodźca” w dyskursie publicznym, jest domyślne przypisanie mu męskiego rodzaju. Co interesujące, kilka dni po opublikowaniu omawianych w niniejszym tekście zdjęć Mariusz Pudzianowski udostępnił na swoim fanpage'u film pokazujący, ,jak wyglądają prawdziwi uchodźcy” - były to materiały przedstawiające kobiety i dzieci podczas przedzierania się przez zaśnieżony las, najpewniej w okolicach Bałkan. Zatem jeśli ,prawdziwi uchodźcy” to kobiety i dzieci, to bezprzymiotnikowi „uchodźcy” (a więc mężczyźni „,w sile wieku”) byliby tak naprawdę „fałszywymi uchodźcami”. Po transformacji semantycznej słowo „uchodźca” zyskałoby więc paradoksalne znaczenie sprowadzające się do swojego własnego pozoru/fałszu. ter performatywu, nie konstatacji, tzn. służy temu, by obrazić, pohańbić, zranić, nie zaś komunikowaniu określonego stanu rzeczy, że jest to słowo, którego znaczenie sprowadza się wyłącznie do użycia, po- 
Wątek seksualny pojawiał się również przy odnoszeniu się do serii napaści, jakie miały miejsce podczas sylwestrowej nocy 2015/2016 w Kolonii i innych miastach niemieckich. Niezależnie od licznych kontrowersji, które wywołała ta sprawa (zarzuty o medialną dezinformację, manipulację i cenzurę - oficjalne dane potwierdzają zdecydowanie większościowy udział imigrantów, w tym uchodźców, w owych atakach), była ona argumentem wspierającym dwie narracje i dowodzącym ich zasadności. Pierwsza miała charakter wyraźnie kolonialny i mówiła o „ich” niepohamowanym i wybujałym popędzie seksualnym (przy czym brak kontroli nad własnymi popędami i instynktami jest cechą barbarzyńską/niecywilizowaną czy „zwierzęcą”). Druga miała charakter heroiczny (a także paradoksalny, patriarchalno-antypatriarchalny wymiar), i można ją streścić w sformułowaniu: Będziemy bronić „naszych” kobiet przed „nimi”. Paradoksalność, czy raczej performatywna sprzeczność, tkwi tu w tym, że stwierdzenie to sankcjonuje męską supremację (uznając mężczyzn za naturalnych obrońców domyślnie słabszych kobiet) oraz przywłaszczanie (bronimy „naszych” kobiet) w tym samym momencie, w którym się im - tj. supremacji i przywłaszczeniu - przeciwstawia („oni” traktują kobiety jako istoty podrzędne, jako „swoją własnośc”, nawet nie uznają „praw kobiet” ${ }^{40}$ !). Na narrację o przemocy seksualnej ${ }^{41}$ bardzo często nakładały się wyobrażenia „skalania” - naruszenia „czystości rasy”, która miałaby też stanowić gwarant i podstawę - jak w przypadku okładki tygodnika „W Sieci” - „czystości” kulturowo-cywilizacyjnej.

Uwaga ta pozwala na przejście do trzeciego stereotypu - znaków selekcji ofiarniczej. W omawianym wypadku podstawowe kryterium stygmatyzujące ma charakter rasowo-etniczny, a najczęściej używanym „raniącym słowem” jest „ciapaty” (określenie czasem stosowane jako przymiotnik, czasem jako rzeczownik, który w liczbie mnogiej przeważnie przybiera nieosobową, resp. odpodmiotawiającą, formę „,ciapate” - „[te] ciapate”). Słownik języka polskiego PWN nie zawiera (jeszcze?) tego słowa ${ }^{42}$. W tworzonym

dobnie jak określenie „sk...syn” nie jest informacją, iż matka osoby, wobec której jest ono skierowane, uprawia nierząd. Spytajmy jednak: jakie szersze konteksty, ramy i wyobrażenia sprawiają, że dane określenie może być używane jako obraźliwe, hańbiące itd.?

Na nic się zdały częste - przynajmniej w mojej „,bańce informacyjnej” - głosy samych zainteresowanych, które twierdziły, że bardziej się obawiają tych, którzy zamierzają ich bronić, niż tych, przed którymi oni chcieliby ich bronić. Retoryka heroiczno-fallogocentryczna pozostała niewzruszona, co samo w sobie powinno podważyć jej rzekomo „równouprawnieniowe” podstawy.

Zestawienie tych oskarżeń z następującym fragmentem Kozła ofiarnego pozwala przypuszczać, że mamy to ponownie do czynienia z transpozycją znacznie wcześniejszego wzorca: „Główne oskarżenia [wobec rzekomych sprawców zbrodni odróżnorodniających - przyp. P.J.] są na pierwszy rzut oka dość zróżnicowane, jednak łatwo ustalić ich zgodność. Chodzi w pierwszym rzędzie o zbrodnie polegające na aktach gwałtu w stosunku do istot, wobec których stosowanie przemocy jest czynem najbardziej zwodniczym czy to w sensie absolutnym, czy jednostkowym”. Girard wymienia tu króli, ojców, symbole autorytetu, ale równie dobrze możemy w ich miejsce podstawić właśnie kobiety, których „uświęcona” pozycja (obiekt czci i troski) nie kłóci się zasadniczo z pozycją podrzędną w ramach tego samego patriarchalnego modelu (R. Girard, dz. cyt., s. 25).

Etymologiczna analiza słowa „ciapaty” wykracza zarówno poza moje kompetencje, jak i ramy niniejszego szkicu. Nie sądzę, by miało ono związek z wychodzącym już z użycia przymiotnikiem „ciapać”, odnoszącym się do akustycznych efektów pewnych czynności (jedzenia, chodzenia po błocie), raczej, jeśli już, 
i redagowanym przez internautów Słowniku slangu i mowy potocznej autor/zy hasła przedstawiają domniemaną etymologię wyrażenia „ciapaty” - pochodzi ono od ćapati, rodzaju indyjskiego chleba pszennego, które to słowo zostało przechwycone przez polskich emigrantów zarobkowych na Wyspach Brytyjskich i używane na określanie Hindusów lub Pakistańczyków [sic!], z którymi musieli rywalizować na rynku pracy. Hipoteza ta poprzedzona jest następującą definicją: „pogardliwe określenie Pakistańczyka, Hindusa lub innego ciemnoskórego człowieka (choć nie Murzyna!)" ${ }^{43}$. Niepokojący jest ten wykrzyknik w nawiasie. Jakby autor/zy hasła ostrzegali przed możliwością naruszenia „naturalnych” rasowych podziałów świata poprzez niewłaściwe używanie rasistowskich określeń. Jakby granica między ciemnoskórym/ciapatym a czarnoskórym/Murzynem wymagała szczególnej ochrony.

Zacznijmy od stwierdzenia, które było już wielokrotnie powtarzane ${ }^{44}$, ale mimo to nie „przyjęło się” w powszechnej świadomości: otóż rasy nie istnieją wjakimkolwiek sensie esencjonalnym („naturalnym”), podobnie jak nie istnieją na przykład kolory określenia różnych ras i kolorów opisują wyłącznie różnicę, wprowadzając fikcyjną nieciągłość wewnątrz atrybutów o charakterze kontinuum i płynnych przejściach (w którym „miejscu” np. „kończy się” czerwony, a „zaczyna” różowy?). Innymi słowy, „rasa” nie jest kategorią naturalną i biologiczną (istoty ludzkie cechuje zbyt duże zróżnicowanie na poziomie tego, co uznawano za wyznaczniki rasowe, by pojęcie to mogło być nie tyle nawet „prawdziwe”, ale chociaż poznawczo użyteczne), lecz kategorią kulturową i dyskursywną. „Naturalizacja” rasy jest uporczywie tkwiącym w szerokiej świadomości atawizmem myślowym po dawno już zdyskredytowanych osiemnasto- i dziewiętnastowiecznych pseudonaukowych koncepcjach (np. Arthura de Gobineau czy Houstona Stewarda Chamberlaina ${ }^{45}$ ). Fakt, że myślenie o rasach w kategoriach „czegoś naturalnego” nadal jest powszechne, wynika z dyskursywnych naleciałości, które na przestrzeni wieków nałożyły się na rasowe klasyfikacje. Rasy zostały wytworzone przez rasizm - dyskurs, który udawał (skutecznie zresztą), że „opisuje” czy „odkrywa” je jako coś względem siebie uprzedniego ${ }^{46}$.

to z będących konsekwencjami „ciapania” cokolwiek dobrotliwymi „ciapkami” - plamami, kropkami, które jednak w omawianym kontekście konotują raczej brud i nieczystość. ta doświadczeń, dziedzictwa wykluczenia i krzywd, która zdolna była do przechwycenia słownika swoich ciemiężców i odwrócenia jego znaczeń - z piętnujących na afirmatywne - budując swą kolektywną tożsamość zarówno przeciw, jak i w oparciu o wytworzoną przez rasistowski dyskurs różnicę. Jak pisze bell hooks: „Część naszej walki o radykalną czarną podmiotowość jest poszukiwaniem sposoby na skonstruowanie tożsamości, która byłaby opozycyjna i wyzwalająca. Niechęć wielu Afroamerykanów do krytyki esencjalizmu spowodowana jest strachem, że może ona doprowadzić do utraty poczucia specyficznego charakteru afroamerykań- 
Cele poznawcze teoretyków rasy maskowały przy tym nadrzędny cel ideologiczny - ustanowienie różnicy, dokonanie podziału i przypisanie mu znaczenia poprzez ciąg hierarchicznych podstawień. Jak pisze Henry Louis Gates Jr.: „zachodni pisarze [...] chcieli zmienić retoryczne figury "rasy» w dosłowność, tak by uczynić je czymś naturalnym, absolutnym i esencjalnym. [...] Nie trzeba wielu dywagacji, by zauważyć, że te pseudonaukowe kategorie same stanowią figury myśli. Czy ktoś widział kiedykolwiek czarnego lub czerwonego człowieka, białego, żółtego lub brązowego? Pojęcia te są arbitralnymi konstrukcjami, a nie odtwarzaniem rzeczywistości. Lecz język nie jest jedynie medium tej często niebezpiecznej tendencji, jest jej znakiem. Zastosowanie języka wyznacza różnice między kulturami i posiadaną przez nie władzą, wyrażając różnicę między poddanymi a panującymi, niewolnikiem a panem" ${ }^{\prime 7}$.

Sądzę, że analogiczne interesy i relacje sił tkwią za wyłonieniem czy wytworzeniem nowej rasy, rasy „ciapatej” ${ }^{48}$, która nie będąc „czarna” (nie mylić z Murzynem!), nadal pozostaje wyraziście i przede wszystkim „nie-biała” (ryzyko pomyłki w tym wypadku najwyraźniej nie istnieje, skoro nie trzeba „nas” przed nim ostrzegać). Rasa „ciapata” sytuuje się więc „pomiędzy”, obramowana dwoma różnicami, z których jedna (oddzielająca „ich” od „,nas”) jest oczywista i wyraźna, druga natomiast (oddzielająca ,ich” od ,innych ich”) dyskretna i grozi nieopatrznym pomyleniem. Komu jednak grozi? Jasnym jest, że zarówno autor/zy definicji, jak i jej implikowani adresaci są „,biali”: to oni muszą uważać, by „właściwie" używać tego określenia, bo przecież trzeba go najpierw używać, by dopiero móc nie mylić. Co istotne jednak, ta różnica różnicy (z jednej strony mała różnica, którą trzeba zaznaczać i której trzeba chronić, z drugiej - radykalna różnica, której nie trzeba sygnalizować i/bo nic jej nie grozi) wyraźnie wskazuje, że ów trzeci element - „ciapaty” - dodany do rasowej wykładni opozycyjno-hierarchicznego schematu „my” - „oni” (tylko dwa rasowe predykaty tworzą bowiem opozycję - „biały” i „czarny”) nie wciska się klinem między

skiej historii, doświadczeń oraz unikalnej kultury z nich wyrastającej. Odpowiednia reakcja na te obawy winna zakwestionować esencjalizm przy jednoczesnym uwzględnieniu roli «władzy doświadczenia». Istnieje olbrzymia różnica między odrzuceniem pojęcia czarnej «esencji» i przyznaniem, że czarna tożsamość narodziła się w nietypowych okolicznościach wygnania i walki” (b. hooks, Postmodernistyczna czerń, przeł. E. Łuczak, w: Kultura, tekst, ideologia, dz. cyt., s. 436-437).

Określenie „ciapaty” używane jest przede wszystkim jako wyznacznik rasowy, ponieważ w zależności od kontekstu (emigracja zarobkowa w Wielkiej Brytanii, kryzys migracyjny) jest w stanie przekraczać podziały narodowe i etniczne, kładąc nacisk na „ciemnoskórość” czy raczej „nie-czarną nie-białość” danego człowieka. Zob. w tym temacie: http://natemat.pl/188643,rasizm-jak-chleb-powszedni-skad-sie-wzielo-slowo-ciapaci [dostęp: 12.02.2017]. Autorka artykułu, Anna Dryjańska, pisze, iż „w tej pojemnej, rasistowskiej kategorii mieszą się zarówno Hindusi, jak i Egipcjanie. Pakistańczycy i część Hiszpanów. Mieszkańcy Arabii Saudyjskiej i Irańczycy. Krótko mówiąc chodzi o niebiałą, nieżółtą i nieczarną część ludzkiej populacji. Czyli - bagatela - kilka miliardów ludzi”, dodając, że ,jest to średnio użyteczne określenie na ludzi, których dzielą tysiące kilometrów, narodowość, przynależność etniczna, religia i kultura”. Uważam, że określenie to, i owszem, jest „średnio użyteczne”, ale tylko w kryteriach opisowych (podobnie jak wszelkie kategorie rasowe czy np. pojęcie „Orientu”), co innego natomiast w rejestrze normatywnym, gdzie zostaje zaprzężone w politykę wykluczania i stygmatyzacji, służąc do jednoczesnego konstruowania i „namierzania” innego/wroga. 
dwa pozostałe, ani nie przemienia całego układu w troisty, ani nie ma mocy zdekonstruowania, w sensie zaproponowanym przez Jacquesa Derridę, samej opozycji, tylko lokuje się po jednej z jej stron, będąc (tak samo jak rasa "czarna") antytezą bieli, czy raczej bielą skalaną, esencjonalnie i nieusuwalnie splamioną.

„Ciapaty” częściowo zazębia się bowiem z drugim „symbolem selekcji ofiarniczej” - z określeniem „brudas”. Stygmatyzujące działanie tego „raniącego słowa” - również funkcjonującego między rejestrem dosłownym a metaforyczno-symbolicznym - objawia się na kilku poziomach. Po pierwsze, jak wspomniałem, wspiera ono dyskurs rasistowski, odnosząc się do koloru skóry, która wyglądać ma jak permanentnie i niezbywalnie zabrudzona skóra „biała” (a więc - de facto - skóra nie-biała). Po drugie, sugeruje cywilizacyjną niższość tych, przeciw którym jest skierowane (nieznajomość zasad higieny osobistej, konotacje związane $\mathrm{z}$ „niższymi” formami pracy fizycznej). Po trzecie wreszcie, operuje na poziomie wyobraźni mitycznej, gdzie materialny brud odnosi do symbolicznej skazy, zmazy, nieczystości, możliwości skalania, które przenosi się, podobnie jak zaraza, poprzez kontakt i uruchamia mechanizm kozła ofiarnego jako rytuału oczyszczenia. Tym sposobem jeden, zdawałoby się: nieszkodliwy, „brudas” jest w stanie uruchomić cały ciąg wykluczających i stygmatyzujących kontekstów na płaszczyźnie kolonialnej, rasowej, klasowej i wyobrażeniowo-mitycznej, a zarazem ożywić historię przemocy, która w nich tkwi.

Przemoc - ostatni z Girardowskich „stereotypów prześladowczych” - obecna była prawie we wszystkich z kilku tysięcy przejrzanych przeze mnie komentarzy. Od przemocy słownej począwszy (,raniące słowa”), przez nawoływanie do przemocy, sugestie przemocowych „rozwiązań” (tak, w tym słowie należy wysłyszeć niemieckie Endlösung), groźby, czyli pewne formy zapowiedzi przemocy fizycznej ${ }^{49}$, po przemoc symboliczną (wykluczające i dyskryminujące hierarchie) i dyskursywną (wtłaczanie uchodźców w odpowiednie ramy, by wzbudzali lęk, niechęć i moralną odrazę).

Komentarze te odzwierciedlają, choć w pewnym wyostrzeniu, tak zwane nastroje społeczne. W raporcie Przemoc jako rozwiązanie? Napływ uchodźców w opiniach Polaków, przygotowanym przez Centrum Badań nad Uprzedzeniami, dobitny jest fakt, jak wielu respondentów opowiada się za stosowaniem różnych form przemocy wobec migrantów (deportacje - $61 \%$, zamknięcie granic - 57,5\%, zatrzymanie w ośrodkach przejściowych - $67,5 \%$, monitorowanie społeczności - $61,5 \%$, a jednocześnie nie rozpoznaje w owych formach przemocy ${ }^{50}$. Niedostrzeganie, „niewidzialność” owej przemocy możliwa jest, jak uważam, dlatego właśnie, że jest to przemoc „uświęcona” ${ }^{51}$.

49 Jak pisze Butler: „Groźba przewiduje lub wręcz obiecuje pewne działania ciała, a jednak jest już sama w sobie cielesnym aktem, a tym samym - gestem zapowiadającym kształt przyszłego działania. Akt groźby i akt, którym się grozi, są oczywiście odrębne, lecz zarazem ze sobą splecione [...]. Groźba otwiera horyzont czasowy zogniskowany wokół celu, jakim jest akt, którym się grozi, zapoczątkowuje szereg działań umożliwiających spełnienie groźby” (J. Butler, dz. cyt., s. 20).

50 A. Świderska, M. Wiśniewski, K. Hansen, Przemoc jako rozwiązanie? Napływ uchodźców w opiniach Polaków, Warszawa 2016, http://cbu.psychologia.pl/uploads/images/foto/Raport_WinSwiHan2016_clean.pdf [dostęp: 13.02.2017]. 


\section{Zakończenie}

Pozostaje jeszcze jedna rzecz: pewna nadwyżka, nadmiar, zbytek przemocy i pogardy obecny w tych czterech tysiącach komentarzy (będących, przypomnę, niewielką częścią mowy nienawiści wypowiedzianej i wypowiadanej, publicznie i prywatnie, w stosunku do uchodźców), który sprawił, że ich czytanie było doświadczeniem niemalże traumatyzującym. Ową nadwyżkę dało się odczuć w dwóch sytuacjach. Pierwszą z nich były liczne komentarze przedstawiające coś w rodzaju „dobrych rad”, jak należy postępować z uchodźcami (nie tylko tymi, którzy włamują się na przyczepi tirów). Począwszy od (często skrupulatnych) instrukcji, jak przemienić naczepę ciężarówki w komorę gazową, przez sposoby zadawania przemocy tak, by nie pozostawiać śladów (ale „by popamiętali”), skończywszy na tym, gdzie najlepiej porzucić zwłoki lub co z nimi zrobić, by nie zostać przyłapanym i uniknąć konsekwencji. Pomysł na „,zrobienie porządku” (ponownie, cóż za gęste symbolicznie określenie) częstokroć ilustrowany był skomplikowanym i wieloetapowym „scenariuszem", utrzymanym w tonie napastliwym lub szyderczym.

Drugim wymiarem owej nadwyżki była pewna mechaniczna repetycja - powielanie dziesiątki, setki razy obelżywych wyrażeń i słów, w przypadku których już jedno ich wypowiedzenie to „za dużo”. Już pierwsze stwierdzenia typu „do gazu” czy „rozstrzelać ich” wywoływały we mnie odruch niezrozumienia i oporu sygnalizowany pytaniem „po co?”. Z każdym kolejnym powtórzeniem - dziesiątym, pięćdziesiątym, setnym - niedowierzanie zawarte $\mathrm{w}$ tym pytaniu zbliżało się do granicy niewypowiadalności; zaczynało brakować słów, by oddać stopień przerażenia, oburzenia, konsternacji, niezrozumienia, zgorszenia, gniewu, niezgody - jakkolwiek nazwać to uczucie, które stopniowo objawiało się na poziomie reakcji somatycznych (być może rzeczywiście metafora trucizny lub porażenia prądem jest tu najbliższa prawdy doświadczenia).

Dariusz Czaja w kontekście okrucieństw i zbrodni wojennych pisał o pewnym „demonicznym nadmiarze”, wprowadzając w swe rozważania cokolwiek nieprzyzwoitą, zważywszy na ich naukowy charakter, figurę Diabła, by za jej/jego pomocą przedstawić „ruch ku nicości, ku bezsensowi, ku opróżnianiu z sensu wszelkiego ludzkiego doświadczenia”, związany ze złem czynionym „po nic”, złem „całkowicie irracjonalnym, apragmatycznym”, złem, które czerpie przyjemność z samego siebie ${ }^{52}$. Coś z owego nadmiaru - toutes proportions gardées - dostrzegam i w tych komentarzach, w nim właśnie upatrując źródło ich toksyczności i zdolności do paraliżowania tak ciała, jak i języka.

51 Naród-suweren przyznaje tedy państwu monopol na stosowanie przemocy, otrzymując w zamian gwarancję bezpieczeństwa i ślubując wspieranie państwa w realizowaniu tego celu (spontaniczne „obywatelskie patrole”, strzegące mieszkańców przed obcokrajowcami, liczne komentarze typu „niech przyjadą do miasta X, to już się z nimi policzymy”). Niestety, naród suweren nie do końca dostrzega, że władza oparta na gwarancji bezpieczeństwa jest jednocześnie władzą wytwarzania niebezpieczeństwa czy decydowania o nim, że zagrożenie, przed którym państwo ma go chronić, od samego państwa może pochodzić. (Oczywiście, twierdzeniom tym daleko do oryginalności, były one powtarzane wielokrotnie przy rozmaitych okazjach, a podstawowym ich źródłem pozostają z pewnością Foucaultowskie analizy władzy).

D. Czaja, dz. cyt., s. 164-165. 
Nie wiem, czy w analizowanym przypadku da się - jak proponuje Butler - tak przearanżować kontekst i scenę wypowiedzi, by „przechwycić”, „przywłaszczyć” sobie, „raniące słowa”, poddać je „reinskrypcji” (J. Derrida) lub „efektowi katachrezy” (G.Ch. Spivak), oderwać je od kontekstu przemocy i wzgardy i otworzyć na nową językową przestrzeń, która nieść będzie polityczną obietnicę. Ich umocnienie w archaicznych mechanizmach kozła ofiarnego nadaje im trwałość znacznie większą niż lokalne układy społecznego pola władzy i sił. Czy zatem szansę rozwiązania odnaleźć można w analizach Girarda? Unaocznienie, a zarazem zanegowanie (choć nigdy nie ostateczne) „wyobraźni prześladowczej" - które Girard przypisuje Ewangeliom, określonym przez niego jako „broń tekstualna” 53 - było możliwe dzięki zmianie w obrębie pozycji narracyjnej. Opisy męki i śmierci Chrystusa - stwierdza autor Sacrum i przemoc - to pierwsze „teksty o prześladowaniach”, nie zaś „teksty prześladowcze” - one przedstawiają „wyobraźnię prześladowczą", w przeciwieństwie do tekstów, które zostały przedstawione $z$ perspektywy „wyobraźni prześladowczej” ${ }^{54}$.

Chodzi więc nie o przearanżowanie sceny wypowiedzi, ale o przekształcenie opowieści tak, by wpleść w nią te sceny wypowiedzi, i by z perspektywy, z której się je przedstawi, widoczne były źródła zawartej w nich przemocy, ich sfabrykowane legitymizacje, aksjologie i retoryki, strukturalne i kontekstualne uwarunkowania, skryte mechanizmy, relacje sił i władzy, które je wytworzyły i które one podtrzymują - słowem, chodzi o to, by w opowieści o zbrodni i ofierze obnażyć wszystko to, co napędzało odpowiedzialne za tę zbrodnię działanie wyobraźni prześladowczej. Potrzebujemy zatem „uchodźczych ewangelii” ${ }^{55}$. Ten tekst starał się być jedną z nich.

Artykuł powstał w ramach projektu badawczego nr 2016/23/D/HS2/03442 pt. „Konstruowanie wizerunku uchodźców w polskim dyskursie publicznym”, finansowanego przez Narodowe Centrum Nauki.

53 Siła owej broni miała przy tym przede wszystkim wymiar jurydyczny i heurystyczny: Ewangelie przedstawiły ofiarę jako absolutnie i w pełni niewinną, a przemoc jako niesprawiedliwą, opartą na fałszywych przesłankach.

54 W niezwykle mocnym zakończeniu Kozła ofiarnego Girard pisze, iż: „[dzięki Ewangeliom] w prześladowaniach historycznych, zarówno średniowiecznych, jak i współczesnych [...], dostrzegamy jeśli nie założycielską przemoc jako taką, to co najmniej namiastkę tej przemocy [...]. Już teraz każda przemoc ujawnia to, co ujawnia Męka Chrystusa, a mianowicie debilny charakter genezy krwawych idoli, wszystkich fałszywych bogów religii, ideologii i polityki. Niemniej mordercy sądzą, że zabijanie ofiar jest chwalebne. Oni także nie wiedzą, co czynią, i powinniśmy im wybaczyć” (R. Girard, dz. cyt., s. 308-309).

Ich podstawą miałyby być nie tyle fabularno-biograficzne podobieństwa między życiem Chrystusa a losem uchodźców, co analogiczne mechanizmy wykluczenia, piętnowania i doświadczania niezawinionych krzywd. W tym aspekcie widać różnicę między głosami Janiny Ochojskiej czy bpa Krzysztofa Zadarko, którzy stwierdzili, że „Jezus był uchodźcą” (co stanowiło asumpt do jałowych sporów biblistyczno-prawniczych, sprowadzających się do tego, czy Jezus „podpada” pod kategorię uchodźcy, jak została ona zdefiniowana w Konwencji Genewskiej; zob. http://www.polityka.pl/tygodnikpolityka/kraj/1688664,2,czy-jezus-byl-uchodzca-sam-kosciol-jest-w-tej-sprawie-podzielony.read [dostęp: 13.02.2017]), a wypowiedzią papieża Franciszka podczas zeszłorocznego Światowego Dnia Migranta i Uchodźcy, który powołując się na św. Franciszkę Ksawery Cabrini, stwierdził: „Niech jej świadectwo pomaga nam opiekować się bratem cudzoziemcem, w którym jest obecny Jezus, często cierpiący, odrzucony i upokorzony" (http://www.pap.pl/aktualnosci/news,771127,papiez-franciszek-w-migrantach-jest-jezus-cierpiacy-odrzucony-upokorzony.html [dostęp: 13.02.2017]. 


\section{BIBLIOGRAFIA}

Agamben G., My, uchodźcy, przeł. K. Galwicz, http://recyklingidei.pl/agamben-my-uchodzcy.

Appadurai A., Strach przed mniejszościami. Esejo geografii gniewu, przeł. M. Bucholc, Warszawa 2009.

Bauman Z., Obcy u naszych drzwi, przeł. W. Micner, Warszawa 2016.

Bauman Z., Wieloznaczność nowoczesna, nowoczesność wieloznaczna, Warszawa 1995.

Bertman Ł., Puchejda A., Wigura K. Negatywny obraz muzułmanów w polskiej prasie. Analiza wybranych przykładów z lat 2015-2016; raport Obserwatorium Debaty Publicznej „Kultury Liberalnej”, https://www.rpo.gov.pl/sites/default/files/Raport\%20Negatywny\%20obraz\%20muzu\%C5\%82man\%C3\%B3w\%20w\%20polskiej\%20prasie.\%20Analiza\%20wybranych\%20przyk\%C5\%82ad\%C3\%B3w\%20z\%201at\%2020152016.pdf.

Biernath M., Różnorodność integracji - jej wymiary i mechanizmy, w: Problemy integracji imigrantów: koncepcje, badania, polityki, red. A. Grzymała-Kazłowska, S. Łodziński, Warszawa 2008.

Butler J., Walczące słowa. Mowa nienawiści i polityka performatywu, przeł. A. Ostolski, Warszawa 2010.

Czaja D., Lekcje ciemności, Wołowiec 2009.

Derrida J., Wrogościnność, przeł. A. Dwulit, w: Wrogościnność. Podejmowanie obcych / Hostipitality. Receiving Strangers, Łódź 2010.

Douglas M., Czystość i zmaza, przeł. M. Bucholc, Warszawa 2007.

Dryjańska A., „Ci cholerni ciapaci”. Gdyby polscy rasiści wiedzieli, skąd wzięło się słowo „ciapaty”, raczej nigdy by go nie użyli,

http://natemat.pl/188643,rasizm-jak-chleb-powszedni-skad-sie-wzielo-slowo-ciapaci.

Gates Jr. H.L., Pismo, „rasa” i różnica, przeł. A. Preis-Smith, w: Kultura, tekst, ideologia. Dyskursy współczesnej amerykanistyki, red. A. Preis-Smith, Kraków 2004.

Gierak-Onoszko J., Czy Jezus był uchodźcą? Sam Kościół jest w tej sprawie podzielony, http://www.polityka.pl/tygodnikpolityka/kraj/1688664,2,czyjezus-byl-uchodzca-sam-kosciol-jest-w-tej-sprawie-podzielony.read.

Girard R., Kozioł ofiarny, przeł. M. Goszczyńska, Łódź 1987.

Goffman E., Piętno. Rozważania o zranionej tożsamości, przeł. A. Dzierżyńska, J. Tokarska-Bakir, Gdańsk 2007.

hooks b., Postmodernistyczna czerń, przeł. E. Łuczak, w: Kultura, tekst, ideologia. Dyskursy współczesnej amerykanistyki, red. A. Preis-Smith, Kraków 2004.

Kamińska M., Konflikt, przemoc, prowokacja w cyberkulturze, w: tejże, Niecne memy. Dwanaście wykładów o kulturze Internetu, Poznań 2011. 
Kucharska M., Leksem 'uchodźca'w języku polskim, (niepublikowana praca magisterska napisana pod kierunkiem prof. K. Kłosińskiej na Uniwersytecie Warszawskim), Warszawa 2016.

Kudyba K., Opinia dotycząca interpretacji znamienia „nawoływania do nienawiści” określonego w art. 256 \$ 1 Kodeksu karnego, http://www.otwarta.org/wp-content/uploads/2015/08/Ekspertyza-prawna-dot.-nawo \%C5\%82ywania-do-nienawi\%C5\%9Bci-K.Kudyba.pdf.

Mikołajewski J., Wielki przypływ, Warszawa 2015.

Mistewicz E., Dekalog antytrollingu, https://wszystkoconajwazniejsze.pl/erykmistewicz-dekalog-antytrollingu.

Morrison T., Waga czerni, przeł. A. Preis-Smith, „Literatura na Świecie” 2002, nr 4-5-6.

Ricoeur P., Symbolika zła, przeł. S. Cichowicz, M. Ochab, Warszawa 2015.

Stephan N., The Idea of Race in Science: Great Britain 1800-1960, London 1982.

Szpunar M., Kultura cyfrowego narcyzmu, Kraków 2016.

Świderska A., Wiśniewski M., Hansen K., Przemoc jako rozwiązanie? Napływ uchodźców w opiniach Polaków, Warszawa 2016.

Todorov T., „Race”, Writing, and Culture, przeł. L. Mack, „Critical Inquiry” 1986, nr 1(13).

Troszyński M., Fundacja Wiedza Lokalna, Raport Mniejszości, Warszawa 2012.

Uchodźcza opozycja, wywiad z Adamem Bodnarem, Rzecznikiem Praw Obywatelskich, „Tygodnik Powszechny” nr 1-2/2017.

Wysocka S. (PAP), Papież Franciszek: w migrantach jest Jezus - cierpiący, odrzucony, upokorzony, http://www.pap.pl/aktualnosci/news,771127,papiez-franciszek-w-migrantach-jest-jezus-cierpiacy-odrzucony-upokorzony.html.

Żyła M., Lampedusa, granica Polski, „Tygodnik Powszechny”, nr 3/2017.

\section{OAUTORZE:}

Piotr Jakubowski (ur. 1985) - doktor nauk humanistycznych w zakresie kulturoznawstwa, absolwent UAM, obecnie adiunkt na Wydziale Nauk Humanistycznych UKSW. Autor monografii „Pułapki tożsamości. Między narracją a literaturą” (Universitas 2016) oraz licznych artykułów naukowych; redaktor prac zbiorowych oraz tematycznych numerów czasopism, thumacz z języka angielskiego. Zainteresowania naukowe: semiotyka kultury, teoria kultury wizualnej oraz przemiany społeczno-kulturowe związane zekspansją nowych mediów. Kontakt:pjakubowski@ymail.com 